\title{
Basement Surface Faulting and Topography for Savannah River Site and Vicinity
}

by

R. J. Cumbest

Westinghouse Savannah River Company

Savannah River Site

Aiken, South Carolina 29808

D. E. Stephenson

D. E. Wyatt

M. Maryak

This paper was prepared in connection with work done under the above contract number with the U.S. Department of Energy. By acceptance of this paper, the publisher and/or recipient acknowledges the U.S. Government's right to retain a nonexclusive, royalty-free license in and to any copyright covering this paper, along with the right to reproduce and to authorize others to reproduce all or part of the copyrighted paper. 


\section{DISCLAIMER}

This report was prepared as an account of work sponsored by an agency of the United States Government. Neither the United States Government nor any agency thereof, nor any of their employees, makes any warranty, express or implied, or assumes any legal liability or responsibility for the accuracy, completeness, or usefulness of any information, apparatus, product or process disclosed, or represents that its use would not infringe privately owned rights. Reference herein to any specific commercial product, process or service by trade name, trademark, manufacturer, or otherwise does not necessarily constitute or imply its endorsement, recommendation, or favoring by the United States Government or any agency thereof. The views and opinions of authors expressed herein do not necessarily state or reflect those of the United States Government or any agency thereof.

This report has been reproduced directly from the best available copy.

Available for sale to the public, in paper, from: U.S. Department of Commerce, National Technical Information Service, 5285 Port Royal Road, Springfield, VA 22161.

. phone: (800) 553-6847

fax: (703) 605-6900

email: orders@ntis.fedworld.gov

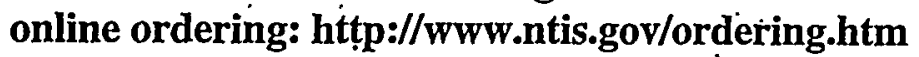

Available electronically at http://www.doe.gov/bridge.

Available for a processing. fee to U.S. Department of Energy and its contractors, in paper, from: U.S. Department of Energy, Office of Scientific and Technical Information, P.O. Box 62, Oak Ridge, TN 37831-0062

phone: (865)576-8401

fax: (865)576-5728

email: reports@adonis.osti.gov . 


\section{DISCLAIMER}

Portions of this document may be illegible in electronic image products. Images are produced from the best available original document. 


\section{BASEMENT SURFACE FAULTING AND TOPOGRAPHY FOR SAVANNAH RIVER SITE AND VICINTY}

by

R.J. Cumbest, D.E. Stephenson, D.E. Wyatt and M. Maryak

Approved By: Devence Ce. Lalomone

Lawrence A. Salomone

SRS Chief Geotechnical Engineer 
$\begin{array}{ll}2.0 \text { INTRODUCTION } & 2\end{array}$

2.1 PURPOOSE AND SCOPE

2.2 BACKGROUND 3

2.3 RATIONALE FOR MAPPING THE BASEMENT SURFACE

3.0 FAULT MAP AND BASEMENT SURFACE TOPOGRAPHY 6

3.1 THE FAUUT MAP 6

3.2 BASEMENT SURFACE TOPOGRAPHY

3.3 DISCUSSION

$\begin{array}{ll}\text { 4.0 RECOMMENDATIONS } & 10\end{array}$

4.1 Effect of FaUlting on Shallow Sediments AND HYDROGEOLOGIC REGIME

4.2 TeChMtQues For CONSTRAINING THE MiNIMUM Ages Of FAULTS 11

4.3 SOUTHERN EXTENT OF THE LOST LAKE FAULT

4.4 SOUTHWEST EXTENT OF THE TINKER CREEK FAULT

4.5 INCORPORATION OF OLDER SEISMIC DATA 13

4.6 ACOUSTIC VELOCITY CONTROL AND CORRELATION BORINGS 13

APPENDIX I: A BRIEF SYNOPSIS OF THE SEISMIC REFLECTION TECANIQUE

APPENDIX II: GRAVITY AND MAGNETIC DATA SET AND ANALYSIS 17

APPENDIX II: BASEMENT LITHOLOGY AND STRUCTURE 19

REFERENCES

LIST OF FIGURES 


\subsection{EXECUTIVE SUMMARY}

This report integrates the data from more than 60 basement borings and over 100 miles of seismic reflection profiling acquired on the Savannah River Site to map the topography of the basement (unweathered rock) surface and faulting recorded on this surface. The boring data, in addition to providing direct measurement of depths to basement are also used to convert the seismic reflection travel times to depth. The information from the seismic reflection profile data is compared with high resolution aeromagnetic and gravity data and the interpretation refined. However, due to the relatively small amounts of offset on most of the faults their gravity and magnetic signatures are typically insignificant (Appendix II).

Because of the resolution limitations of the gravity and magnetic techniques the existence of faulting is determined from the offset of the unweathered rock (basement) event on the seismic reflection profiles. The ability to resolve offset with this technique is limited primarily by the frequency content of the reflected energy. This puts a limit on the certainty with which smaller offsets may be determined. The offset magnitude relative to the wavelength of the reflected energy is indicated on the fault map in a semiquantitative way. In addition, due to data coverage, uncertainties exist in fault extents and orientations. The uncertainty in fault orientations and extents are also indicated. Previous studies have reported fault maps for Savannah River Site (see Domoracki, 1994 for the most recent and comprehensive). However, the fault map reported in this study is the first comprehensive fault map to incorporate and communicate the confidence with which this faulting is known. This allows evaluation of the significance of faulting when considered for future facility siting and particularly for their potential to impact remediation efforts or contaminant flowpaths.

The sediments immediately above the basement surface are Late Cretaceous and younger in age. Therefore faulting that disrupts the base of these sediments may be considered to be younger than the Early Cretaceous - Late Cretaceous boundary (97.5 million years). 
However, several factors make determination of the youngest age for faults in the Coastal Plain problematic. The relatively small offsets exhibited by even the largest of these faults in conjunction with the poorly consolidated nature of the sediments minimizes the possibility for significant surface expression. Also, the fluvial nature of the shallow subsurface sediments complicates the resolution of structural disruption of these geologic units. Even if structural disruption of the near surface is established the age of the near surface sediments, except in very localized areas, is 16 to 25 million years. When considered relative to the age criteria stated in 10CFR100 Appendix A, which considers capability demonstrated for movement at or near the ground surface in the past 35,000 years or movement of a recurring nature in the past 500,000 years the problematic nature of this approach is evident. This fact has been recognized by the Nuclear Regulatory Commission and others, "In the Central and Eastern United States characterization of seismic sources is more problematic than in the active plate margin region because there is generally no clear association between seismicity and known tectonic structures or near - surface geology. In general, the observed geologic structures were generated in response to tectonic forces that no longer exist and have little or no correlation with current tectonic forces." (NRC Regulatory Guide 1.165). Based on our review of existing data, consideration of historic seismicity, and other studies referenced in this report we find no evidence for capability on any presently identified faults at Savannah River Site.

\subsection{INTRODUCTION}

\subsection{Purpose and Scope}

The purpose of this study is to review all relevant work concerning basement structure for Savannah River Site and vicinity and to map the basement surface topography and faulting recorded on this surface. The resulting fault map indicates specific areas where the structural disturbance of the overlying sedimentary sequences may have significant influence on environmental remediation efforts or transport of contaminants. The scope of work involved detailed review and integration of the data and results reported in the following: 
Seismograph Service Corporation, 1971;

Daniels, 1974;

Daniels and others, 1983;

Chapman and DiStefano, 1989;

Anderson, 1990;

Domoracki, 1994;

LaTour and others, 1995;

Shervais and others, 1997;

Dennis and others, 1997;

Bartholomew and others, 1997.

A benchmark study (Domoracki, 1994) integrated the gravity, aeromagnetic, and sitewide seismic reflection data to produce a comprehensive fault map for Savannah River Site. Since this study was published, new seismic reflection data have been acquired specifically for refinement of the fault map or in support of other characterization projects. In addition, since this map was produced several other relevant geologic studies relating to Savannah River Site basement geology and regional fracture studies have been completed. In light of these new data and studies a synthesis of this information is presented in this report

\subsection{Background}

As discussed below the faulting recorded by the sub-Cretaceous unconformity (basement surface) is constrained to be Early Cretaceous ( 97.5 million years) or younger in age. No detailed information is provided as part of this report concerning the effects of faulting on overlying sedimentary sequences. However, previous extensive investigations at the Savannah River Site have made highly detailed and focused studies of these effects (Final Safety Analysis, Defense Waste Processing Facility; Preliminary Quaternary and Neotectonic Studies, Savannah River Site, South Carolina, Final Report, Prepared by Geomatrix Consultants, Inc. 1993; Confirmatory Drilling Project Final Report, WSRCRP-94-0136) and found no evidence for capability of these structures as defined in Appendix A, 10CFR100. In addition, a sitewide search for indicators of paleoseismic 
activity yielded negative results (Paleoliquifaction of SRS, Subcontract C001015P, Task 33, "Paleoliquifaction Assessment of SRS" Deliverable Item number 3, Science Applications International Inc.). Based on the results of these studies and relatively low levels of historic seismicity in the region it is our opinion that the potential for these structures to be capable per 10CFR100, Appendix A is negligible.

Also, since the effects of faulting on the overlying sedimentary sequences are not the focus of this study, specific information concerning the effects of faulting on contaminant flowpaths is not presented. However previous detailed studies that address this issue have shown the value of this type of information for environmental remediation (Wyatt and others, 1997a; Wyatt and others, 1997b; Wyatt and others, 1997c). The utility of the fault map presented here is to provide a guide for more focused studies that address the specific issues described above.

In the cases of the more well studied examples (i.e. Pen Branch and Crackerneck) faulting and fault orientations are well constrained. However, for most other cases the presence of faulting and fault extent and orientations are known to various degrees of certainty. This uncertainty is due to the resolution limits of the geophysical technique or to insufficient data density. Recommendations are made for future studies to resolve some of these uncertainties and to address important issues related to constraining their effects on environmental remediation efforts and to a lesser extent on the movement history of these structures.

\subsection{Rationale for Mapping the Basement Surface}

A depositional unconformity (sub-Cretaceous unconformity) marks the separation between Late Cretaceous (less than 97.5 million years) sediments and Mesozoic and Paleozoic rocks (basement) at Savannah River Site. This surface ranges in depth from about 200 meters in northern parts of the site to 400 meters in the south. It separates relatively hard and dense igneous, metamorphic, and lithified sedimentary rocks along with a mantle of their weathered equivalents (basement) from overlying loosely to unconsolidated sediments. Although, in detail the presence of the weathered mantle complicates the picture, the sub-Cretaceous unconformity marks a relatively narrowly 
defined zone across which the physical properties of the geologic materials show large changes. This makes this geologic marker easily identified both from a geologic and geophysical perspective.

The sub-Cretaceous unconformity generally has an easily identified geologic and geophysical signature, and it makes a reliable strain marker that is used to determine the relative ages of structures that it records. That is, any offset or secondary deformation of this marker horizon and immediately overlying sediments is younger than the development of the unconformity surface and deposition of the sediments immediately above. Since the base of the sediment package immediately above the unconformity is Late Cretaceous in age then the deformation of these units is constrained to be post-Early Cretaceous (i.e. less than 97.5 million years old).

The large physical contrasts in both density and acoustic velocity that occur in the subsurface in the vicinity of the sub-Cretaceous unconformity make this zone relatively easy to map using acoustic geophysical techniques (seismic reflection, seismic refraction: see Appendix I for a brief description of the seismic reflection technique). On almost all seismic reflection surveys conducted at Savannah River Site, the transition between relatively hard, dense sub-Cretaceous basement rocks and the loosely consolidated overlying sediments typically exhibit the largest amplitude and most coherent reflected energy (Figures 1 and 2). This makes the seismic reflection technique the most useful and highest resolution technique available for mapping this feature in the subsurface.

The transition zone associated with the sub-Cretaceous unconformity is also marked by relatively large contrasts in density and magnetic properties. However, the largest offsets associated with basement faulting observed on the Savannah River Site are on the order of 40 meters. Based on nominal values for magnetic susceptibilities of the sub-Cretaceous basement rocks, deformations of this magnitude should have a resolvable magnetic signature (see Appendix II). The availability of high resolution aeromagnetic surveys for Savannah River Site and surrounding vicinity therefore contribute useful information that may be used to further constrain the seismic reflection data.

Modeling of deformations of this magnitude using nominal densities for the subCretaceous rocks indicate that their gravity signature is relatively low compared to the 
resolution limits of currently available gravity survey technology (see Appendix II). However, for the largest offsets in relatively mafic lithologies, a gravity effect may be detectable.

The geophysical signature of the top of the sub-Cretaceous basement rocks occurs where the physical properties exhibit their highest contrast. In many places the weathered mantle materials may exhibit physical properties similar to those of the overlying Late Cretaceous sediments. The consequence of this is that geophysical techniques actually map the surface of relatively unweathered rock instead of the sub-Cretaceous unconformity itself, because by definition the sub-Cretaceous unconformity coincides with the top of the weathered layer. Assuming that deformations mapped by geophysical techniques on the unweathered rock surface are also present on the sub-Cretaceous unconformity allows these deformations to be constrained to post-Early Cretaceous (i.e. less than 97.5 million years) in age with the caveat that this age constraint is based on the assumption stated above.

\subsection{FAULT MAP AND BASEMENT SURFACE TOPOGRAPHY}

\subsection{The Fault Map}

The presence of faulting is determined primarily from offset of the top of the unweathered rock event (Figures 1 and 2) on seismic reflection data. These data were interpreted on a LANDMARK workstation, which allowed the horizontal and vertical scaling relationships of the seismic profiles to be easily changed. Confidence in the resolution of the offset of this event is characterized in terms of the wavelength of the reflection amplitude. In practice offsets greater than one-half wavelength (Figure 2) are readily identified on the seismic record and are almost certainly the result of faulting of this surface. Such effects may also result from processing errors (statics). However, these types of errors show a time constant shift in the data throughout the entire record. Potential offsets were screened for this possibility. Corroborating evidence for the geologic reality of the offset was also sought. This included deformation of the sediments 
immediately above the offset which show effects such as fault propagation folding (Figure 2) as discussed in Cumbest and Domoracki (1998) or dip in the trace of the offset in events above the unweathered rock event. Offsets of one quarter wavelength (Figure 2) are near the resolution limit of the seismic data and the geologic reality of these features are highly uncertain when considered as individual data points. Offsets of one quarter wavelength or less were identified only in cases where faults were projected to cross a seismic profile and it was considered that some effects may be indicated or where a change in slope of the unweathered rock event indicated that faulting may be present.

Conversion of these wavelengths to distances is dependent on the frequency content of the seismic data (see Appendix I). Note in figure 2 that the unweathered rock event is characterized by a central positive amplitude peak (dark blue line) flanked by two negative amplitude peaks (dark red lines) on each side. The wavelength of this event can be characterized by the distance from the two negative peaks. In this case this is approximately 15 milliseconds ( $t$ ). Assuming a nominal velocity of 2000 meters per second (v) the characteristic wavelength (l) for this event may be calculated by:

$$
l=v t
$$

or 30 meters. However when offset of the wavelet is considered the one-way travel time must be used, ( 7.5 milliseconds); this will lower the distance by a factor of 2 (i.e. offset of one wavelength will be 15 meters, 7.5 meters for one-half wavelength, or 3.75 for one-quarter wavelength).

This offset distance must be considered a maximum, however. The example examined above has a bandwidth (frequency content) from 30 to $120 \mathrm{~Hz}$. However, some of the high resolution seismic profiles have bandwidths as broad as 20 to $300 \mathrm{~Hz}$ which means that the wavelets will be significantly narrower and characteristic offset distances for the wavelengths smaller. In addition to the frequency content of the seismic signal the wavelength of the unweathered rock event is also dependent on the character of the transition in physical properties across the basement surface. In areas where the basement is composed of crystalline rock this transition is abrupt, into extremely high velocity dense rocks. This results in a relatively narrow wavelet. However, in areas underlain by 
Triassic sediments (Appendix III: Figure 6a) this transition appears not to be so abrupt and longer wavelength wavelets are seen. However, the prime reason for characterizing the offsets in terms of wavelength was to communicate confidence in identification, not offset distance. Offset distance may be obtained by examination of the map of basement topography (Figure 3).

The locations of the seismic data set used for this study are illustrated in Figure 4. Figure 4 also shows the bandwidths of the seismic data and offsets indicated on the seismic lines as point symbols. The few points not on the seismic lines are from the Seismograph Services Corporation program, which does not exist, in digital form. In addition, the faults, which have the highest confidence in terms of their orientations and existence, are indicated along with named faults that have appeared in the previous literature.

Fault extents and orientations (Figure 5) are determined based on correlation of basement offsets between seismic reflection profiles. This correlation was based on the sense of offset and similarity of the geometry of the reflection event on either side of the offset. In addition, the extent and correlation was also based on the gravity and magnetic signature if possible (see Appendix II). In areas with little seismic reflection coverage or where the offsets do not show distinctive characteristics the correlation between seismic lines and fault extents are uncertain. This uncertainty is expressed on the map. Solid lines for faults between seismic lines indicate the highest levels of certainty. Long dashed lines indicate inferred extents and dotted lines are hypothetical extents. For unconnected individual points inferred orientations were estimated based on the gravity and magnetic data. The character of the offset on the seismic reflection profile was also considered for this estimate. Sharp distinct offsets indicate that the seismic reflection profile probably crossed the fault at a high angle. 


\subsection{Basement Surface Topography}

The topography of the basement surface (Figure 5) was determined by mapping the two-way travel time for the unweathered rock event from the seismic reflection data and converting this information to depth using borings on or very near the reflection profiles. The resulting surface was then corrected using other available borings. In detail this process consisted of:

1. modeling the travel time data as a regularly spaced grid, taking into account the faulting determined from the fault map,

2. determining the depth to the unweathered rock in deep borings located on or very near the seismic profiles,

3. calculating the interval velocity from datum to the unweathered rock using the depths from the near profile borings and the travel times at the boring locations,

4. modeling the resulting interval velocity information as a regularly spaced grid,

5. calculating the elevation of unweathered rock using the travel time, velocity and datum information,

6. correcting the resulting basement surface elevation grid using other available borings that were not in the vicinity of the seismic reflection profiles and that were not used in the velocity determination.

The resulting map shows the gentle southeastward dip of the basement surface characteristic of the southeastern United States. This surface is modified locally by small discontinuities at the fault locations. Major perturbations in the topography occur associated with the Pen Branch, Crackerneck, Atta and Tinker Creek faults.

\subsection{Discussion}

An extensive study of Savannah River Site and the surrounding region (Bartholomew and others, 1997) discovered fracturing and faulting in a broad range of orientations and ages, some as young as Pliocene ( $5.3-1.6$ million years ago; Figure 6). These features occur in distinct sets that result from the prevailing regional stress field at 
the time of their creation. Detailed stratigraphic control which allowed relative dating of these fracture sets enabled Bartholomew and others (1997) to associate this broad range in orientation with a time varying regional stress field (Figure 6) that resulted in fracturing and faulting from the Triassic to the Pliocene. The wide range of orientations exhibited by the faulting on Savannah River Site probably results from this same phenomenon and as a result of being subsidiary structures to the major features listed above.

Examination of the magnetic data (Appendix II) shows two prominent magnetic lineaments that are associated with Paleozoic faulting in the basement. Several post-Early Cretaceous faults appear to occur associated with these features. However, these faults appear not to show significant lateral extent except possibly in the northwest part of the site. This would seem to indicate that these features experienced very localized, minor reactivation in post-Early Cretaceous time.

The largest offsets are seen in association with the Pen Branch, Crackerneck, Atta, and Tinker Creek faults. These faults show offset of the basement surface that is typically several wavelengths in magnitude (greater than approximately 30 meters; Figure 7). The offset magnitude and extent of these faults make them distinctive relative to the other faulting observed in the seismic data. This observation in conjunction with the seismic data coverage suggests that these are probably the only regionally significant post-Early Cretaceous faults on the Savannah River Site. Although numerous other faults are shown on the fault map most of these have relatively small offsets compared with the examples listed above and they appear to be of relatively limited extent.

\subsection{RECOMMENDATIONS}

This report did not focus on the effects of deformation in shallow sediments on the Savannah River Site. However, deformational features in the shallow subsurface may have significant effects on hydrologic properties and contaminant transport in these units. For this reason deformation of the sediments above the basement has possible consequences for environmental remediation efforts. The fault map indicates locations 
where structural effects resulting from deformation are likely or possible. The following recommendations are focused on determining the likelihood or magnitude of these effects and their possible consequences on environmental remediation efforts.

\subsection{Effect of Faulting on Shallow Sediments and Hydrogeologic Regime}

Several faults shown on Figure 4 occur in areas where they may have significant impacts on contaminant transport. The effects of fault related deformation in the shallow sediments on the Savannah River Site and consequent effects on the hydrogeologic regime has never been investigated in detail. A program at an appropriate location to map in detail the shallow sediment deformation and determine hydrogeologic consequences is proposed. This program would consist of cone penetrometer information, combined with radar and modeling to map the subsurface detail along with a few pump tests to determine the effects on hydrologic properties.

\subsection{Techniques for Constraining the Minimum Ages of Faults}

Although the sub-Cretaceous unconformity allows maximum age constraints to be placed on faulting, minimum age constraints are significantly more difficult to determine. In some cases it may be demonstrated that younger sedimentary sequences truncate the deformation associated with post-Late Cretaceous faults. In the cases where this can be demonstrated a minimum age is indicated by the age of the truncating sediments. However, in many cases the presence of a truncating layer cannot be demonstrated and the deformation associated with the faulting may be traced into the very shallow subsurface or the surface. Except in localized areas such as alluvial deposits or where soil horizons are developed the surface sediments on Savannah River Site are approximately 16-25 million years old or older. This means that faults that deform these sediments may only be constrained to be younger than 16-25 million years which is of limited utility in evaluating "capability" in the regulatory sense. For both of the reasons 
listed above this approach may in many cases lead to ambiguous results. An alternative approach is needed.

Other dating methods have greater potential for dating these young structures. Most of the fracturing associated with these faults, both in the basement and in Coastal Plain sediments contain minerals that can be demonstrated to have formed in association with the fracturing and therefore the faulting. These minerals may be dated by radiometric or magnetic resonance methods. Obtaining formation ages of these minerals may allow minimum faulting ages to be constrained.

The dating systematics of the methods and minerals listed below are fairly well known. A pilot study could be conducted that will evaluate the utility of the following dating methods and minerals for constraining fault history at Savannah River Site. The material for this study will be collected from existing basement core or suitable outcrops of Coastal Plain sediments on the Savannah River Site. Electron spin resonance dating of quartz fracture material Argon radiometric dating of illite fracture material $\mathrm{Rb}-\mathrm{Sr}$ radiometric dating of silicified zones from basement core

The specific purpose of utilizing these techniques will be to determine the age of fracturing and mineral growth associated with faulting and obtain the age of the youngest movement. Compared to the capability evaluation techniques currently employed such as shallow subsurface profiling with multiple drill holes or cones the techniques listed above are relatively inexpensive and can be accomplished in a fraction of the time.

\subsection{Southern Extent of the Lost Lake Fault}

The Lost Lake Fault has been mapped primarily in the AM area where it appears to exert significant control on contaminant flow paths. However, due to lack of seismic reflection data the southern extent of this fault has not been determined. It has been conjectured that this structure may be associated with preferential flow of contaminants from AM area to more southerly areas where these contaminants are found. Additional seismic data focussed on mapping the southern extent of this fault is recommended. 


\subsection{Southwest Extent of the Tinker Creek Fault}

The Tinker Creek fault may be a fault of regional importance. Other studies (Domoracki, 1994) have interpreted the Tinker Creek fault to continue across Savannah River Site to the southwest parallel to Upper Three Runs Creek. If this is the case it will pass very near several critical facilities that have identified groundwater plumes. Based on current data this issue is unresolvable. A seismic reflection program consisting of short but carefully placed seismic reflection profiles is recommended to resolve the potential impact of faulting to the aquitards and groundwater flow.

\subsection{Incorporation of Older Seismic Data}

The first seismic reflection program conducted on the Savannah River Site by Seismograph Service Corporation consisted of several regional lines that cover portions of the Savannah River Site not covered by more recent data. Some of this information has been incorporated into the fault map. However this information exists on paper records and is of limited utility in the construction of the map of the basement surface. It is recommended that these data be reprocessed and incorporated into our electronic data base and the information be used to produce a more accurate map of the basement surface. In addition these data may also be used to address recommendations 4.1, 4.3 and 4.4 above.

\subsection{Acoustic Velocity Control and Correlation Borings}

In order to obtain the most information from the seismic program outlined above and to cover portions of the site that lack this type of data two basement borings are recommended. The location of these borings would be dependent on the location of new seismic lines. 


\section{APPENDIX I: A BRIEF SYNOPSIS OF THE SEISMIC REFLECTION TECHNIQUE}

\section{Data Acquisition}

The basic idea behind the seismic reflection technique is to create an elastic pulse on the surface of the earth and to map the time of the return echoes of this pulse as it encounters and is reflected from subsurface geologic interfaces (Figure 8). The elastic energy in the pulse may occur in the form of both shear waves or compressonial waves and both are used in practice. However, for technical reasons the most commonly used are compressional waves (acoustic energy) and this will be assumed for the following discussion.

The reflected acoustic pulses are detected on the surface with a geophone (earth coupled microphone) or regularly spaced linear array of geophones. Ideally, the recording sequence is started simultaneously with the initiation of the acoustic pulse and continues for some predetermined amount of time selected to sample reflected energy over the depths of interest. This will result in a record of acoustic amplitude with time. The amplitude maxima will correspond to times that the reflected pulses reach the surface. Performing this activity repetitively at regularly spaced intervals along the surface results in a profile of the subsurface that maps the subsurface reflecting interfaces in terms of their reflection amplitudes and reflection times. Note however that the reflection times are two-way travel times. That is the pulse must travel from the surface to the reflecting interface and back to the surface. This fact is important when it becomes necessary to determine the true depths to the reflecting interfaces or distances between interfaces. Note also that if an array of geophones is used each time that this activity is performed that many subsurface points along each reflecting interface are sampled at once. If the recording activity is moved along the surface in the direction of the geophone array at some distance less than length of the array then the next record generated will resample some of the subsurface points sampled by the initial record. Moving the recording array forward incrementally in this manner allows each subsurface point to be 
sampled many times. This sample redundancy is a very powerful technique used for noise reduction.

\section{Reflection Characteristics}

The ability of geologic interfaces to reflect acoustic energy is a function of the contrast in acoustic velocity $(V)$ and density $(\rho)$ across the interface. The relative amount of acoustic amplitude in the pulse reflected by an interface is expressed functionally by the reflection coefficient $(\mathbf{R})$ :

$$
R=\left(\rho_{2} V_{2}-\rho_{1} V_{1}\right) /\left(\rho_{2} V_{2}+\rho_{1} V_{1}\right)
$$

Where subscript 1 refers to material above the interface and subscript 2 material below the interface.

For resolution purposes a pulse of short time duration is required so that separate pulses will be reflected from closely spaced interfaces. In a perfect world the ideal pulse would be a spike of zero time duration. However, a pulse with this characteristic would require an frequency content with infinite bandwidth. Since no real acoustic pulse source can meet this criterion in reality acoustic pulses have finite bandwidths and consequently are extended in time.

The reflection response of a layered earth with multiple interfaces may be modeled by combining the amplitude function that characterizes the real pulse (wavelet) with the reflection coefficient characterization of the subsurface interface structure (Figure 9). The reflection coefficient characterization is obtained by placing the reflection coefficients at the correct intervals determined by the interval velocities of the material between the interfaces. This process is called convolution and effectively is accomplished by replacing the reflection coefficients on the time axis with scaled versions of the pulse wavelet. Note that this process is relatively straight forward as long as the reflection coefficients are spaced farther apart than the pulse duration. Of course this is never the case. For this and other reasons, simple reflected scaled copies of the original pulse are never seen in practice. Due to the relatively complex nature of even the most simple geologic settings the reflection coefficients are closely spaced relative to the duration of the wavelet. In this case the amplitudes of the overlapping wavelets must be 
summed in small time increments to obtain the resulting pulse shape. This is essentially an interference effect and the result is that the reflection time record is composed of wavelets that are convoluted combinations of the reflection coefficient series and the original source pulse.

\section{Simple Interpretation - Conversion from Time to Depth}

The seismic reflection profile is composed of many time records (traces) placed side by side. These represent the two-way travel time characterization of the subsurface interface structure with each trace sampling points on the interfaces at laterally spaced increments. In order to convert the reflection times to depth, or difference in times to offset, a function representative of the subsurface velocity structure is required. The better this velocity function is known the more accurately the depth conversion can be made.

A simple estimate can be made if the depths to reflecting interfaces are known at a control or several control points (i.e. borings). If the depth is known and the one-way reflection time for this interface obtained from the reflection record the velocity function at the control points may be calculated. This velocity function can then be applied to the rest of the reflection record to convert the time profile to a depth profile. However, this method has two main drawbacks. Typically velocity is not only a function of depth but it also varies laterally due to geologic factors such as facies changes. This may introduce significant error in the time to depth conversion depending on the geologic situation and the number of control borings. However, even in relatively simple geologic environments where lateral velocity variations may not be significant the velocity determination process described above requires that a specific reflection event be confidently assigned to a specific geologic interface. As discussed previously, since the recorded wavelet is never a scaled copy of the source wavelet but a convoluted version this assignment may be highly uncertain.

A more reliable way to determine the amplitude response of the subsurface and time to depth conversion is to physically measure the density and velocity properties of the subsurface materials at closely spaced vertical increments. This is accomplished with 
logging tools in boreholes that penetrate the interval of interest. With this information a reflection coefficient series may be calculated for the boring that is representative of the subsurface at that location. The amplitude characterization of the pulse (pulse wavelet) may then be convoluted with the reflection coefficient series to produce a reflection record model. These models are called synthetic seismograms and may be compared with real reflection profiles that pass through or very near the boring to confidently identify amplitude variations and assign reflection events to real geologic features (see Figure 1).

\section{APPENDIX II: GRAVITY AND MAGNETIC DATA SET AND ANALYSIS}

\section{Gravity Field}

As discussed in Appendix III the basement beneath Savannah River Site, particularly the crystalline basement, is composed of relatively dense rocks ranging in composition from felsic ( $\rho$ approximately $2.65 \mathrm{~g} / \mathrm{cc}$ ) to mafic ( $\rho$ approximately $3.0 \mathrm{~g} / \mathrm{cc}$ ) compared with the overlying sediments ( $\rho$ approximately $2.0 \mathrm{~g} / \mathrm{cc}$ ). Offset of the surface of the basement will bring the upthrown side of the offset nearer the surface and could potentially be detected as anomalous behavior in the gravity field measured at the surface.

A comprehensive gravity data set for Savannah River Site and vicinity has been compiled from various sources by Domaracki (1994). These data were collected along traverses on Savannah River Site that in many cases correspond to seismic reflection profile locations. Figure 10 shows the result of modeling the gravity response for a 30 meter offset on the basement surface using nominal densities for sub-Cretaceous basement lithologies. This modeling indicates that that the largest possible anomaly amplitude (approximately $1 \mathrm{mGal}$ ) results from mafic lithologies and decreases to approximately .7 to $.6 \mathrm{mGal}$ for metamorphosed mafic to felsic lithologies. The nominal precision for currently available gravimeters is on the order of $0.1 \mathrm{mGal}$. However, the large number of corrections that must be made to gravity data degrade the precision of the final result to significantly more that $0.1 \mathrm{mGal}$. This makes the anomaly amplitudes that would be expected from the largest faults ( 30 meters) very close to the detection 
limit. In order to see an anomaly of this magnitude would require that the data set be contoured with a minimum contour interval of at least $0.5 \mathrm{mGal}$. Most regional gravity sets are contoured at the $1 \mathrm{mGal}$ level or courser. Also, these anomalies are limited in spatial extent so that gravity measurements would be necessary at closely spaced intervals. For this reason the contoured region on figure 12 is limited to the area where closely spaced gravity data are available.

Comparison of the sub-Cretaceous basement lithology map (Figure 11) with the gravity map (Figure 12) indicate that the features on the gravity map correlate primarily to density variations resulting from changes in lithologic composition rather than the geometry of the basement surface. Figure 12 shows the post - Early Cretaceous faults displayed on the Savannah River Site regional gravity map contoured at the $0.25 \mathrm{mGal}$ level. Notice that in many cases the fault offsets result in localized variations in the gravity field that produce minor deflections in the contours. These faults appear to produce no laterally extensive gravity field effects and for this reason the gravity technique is of limited utility for determining either the presence, extent or orientation of faulting on the basement surface.

\section{Aeromagnetic Field}

The basement rocks beneath Savannah River Site also are made up of lithologies (Appendix III) that contain significant amounts of magnetite, particularly the more mafic compositions. This mineral is ferromagnetic and imparts a strong induced magnetic field in rocks in which it is found in significant quantities. In an analogous way to gravity, offset of the basement surface may result in magnetized rocks closer to the surface on one side of the offset and produce anomalous behavior in the magnetic field measured.

A high resolution aeromagnetic data set is also available for the Savannah River Site and surrounding vicinity (Daniels, 1974). These data were collected at $500 \mathrm{ft}$ altitude along northwest - southeast trending flightlines spaced 0.5 miles apart. Figure 10 shows modeled magnetic anomalies resulting from a 30 meter offset on the basement surface for several different lithology types and fault orientations. Note that the magnetic field anomalies range in amplitude from 5 nanoTeslas (a unit of magnetic field strength $=$ 
gamma) to about 40 nanoTeslas for mafic compositions and east-west orientations. The behavior is dependent on the orientation of the fault because the earth's field direction at this latitude has a significant lateral component (i.e. $\mathrm{N}$ - S).

Figure 13 shows the Savannah River Site and vicinity aeromagnetic data with the post-Early Cretaceous faults. Again comparison with the sub-Cretaceous lithology map (Figure 11) shows that the primary features on the aeromagnetic map correspond to lithology differences except for two well defined linear anomalies that transect the site in a northeast direction. These two linear anomalies are characteristic of the Paleozoic Eastern Piedmont fault system and have been identified as such in several previous studies. Several of the post-Early Cretaceous faults appear to occur on or near the linear magnetic anomalies that correspond to the Paleozoic basement faults. However, these faults are of limited extent and appear to result from localized reactivation of the ancient Paleozoic structure.

Smaller linear magnetic anomalies appear to correspond with several of the other offsets (for example the Atta fault). Since the magnetic field, based on modeling showed significantly more potential for displaying anomalous behavior resulting from offset of the basement surface it was used as an indicator of orientation if other information was lacking.

\section{APPENDIX III: BASEMENT LITHOLOGY AND STRUCTURE}

In order to model the geophysical response to offset of the basement surface information is required about the compositions and distributions of the basement rocks. The compositions are used to infer physical properties such as density and magnetic susceptibility. Comparison of the basement lithology map (Figure 11) with both the gravity and magnetic data (Figures 12 and 13) show that in most cases the more significant features result from changes in lithologic type and therefore physical properties rather than basement topography. In addition, the basement rocks beneath Savannah River site record several generations of deformational features resulting from many tectonic events. These features range from brittle fracturing and faulting to regional 
scale shear zones. The largest of these shear zones forms a distinct lineament in the magnetic data (Figure 13). Knowledge of the deformation recorded in the basement rocks is also necessary in order to determine the relationship of this structure to more recent faulting.

Information concerning the composition and structure of the sub-Cretaceous basement beneath Savannah River Site has been directly sampled by drill core from core holes deep enough to penetrate the overlying sediments. In addition, indirect information concerning the composition of these rocks and their distributions is obtained by geophysical techniques. Several past studies have addressed this aspect of Savannah River Site geology. (Marine and Siple, 1974; Daniels, 1974; Daniels and others, 1983; Cumbest and others, 1992; Stephenson and Stieve, 1992; LaTour and others, 1995, Shervais and others, 1997; Dennis and others, 1997).

The most recent and comprehensive of these studies( Latour and others, 1995; Dennis and others 1997; Shervais and others, 1997) employed detailed geochemical analysis and structural studies. These studies determined that the lithologies and structures for the sub-Cretaceous basement are basically similar to that seen in the eastern Piedmont province as exposed in other parts of the southeastern United States. Generally these rocks form a crystalline terrain in northern portions of the site and a basin containing Mesozoic age rift related rocks (Dunbarton Basin) in the south. The crystalline rocks form a volcanic - intrusive sequence of calc-alkiline composition, portions of which record both ductile and brittle deformational events. These relationships indicate that these rocks are the metamorphosed and deformed remnants of an ancient volcanic arc that are interpreted to be Carolina Terrane equivalents.

The crystalline rocks were mapped as three formations by Mauldin and others, (1977) and Dennis and others, (1977: Figure 11). The Crackerneck formation consists of weakly metamorphosed and mildly deformed volcanic rocks of intermediate to felsic composition. The DRB Formation (named after the Deep Rock Borings in which it is found) consists of moderately metamorphosed and highly to moderately deformed volcanic and plutonic rocks of mafic to intermediate - compositions. The PBF Formation (named after the Pen Branch Fault borings in which it is found) contains strongly 
metamorphosed gneisses that have experienced relatively high thermal effects and appear to be deeper equivalents of the DRB Formation. The plutonic rocks of both the DRB Formation and PBF Formation have radiometerically dated crystallization ages of 620 my. Based on the association of these rocks with the Carolina Terrane the metavolcanic rocks of the Crackerneck Formation are interpreted to have been deposited unconformably on the DRB formation at about $620 \mathrm{Ma}$.

Subsequent to the formation of this volcanic stratigraphy these rocks underwent multiple deformational episodes and chemical changes. The rocks of the DRB formation record highly developed deformational fabrics that indicate that these rocks have undergone significant amounts of ductile shearing at moderately high temperatures. These fabrics, in association with the superposition and juxtaposition of the higher temperature PBF formation indicate that this deformation resulted from thrust and strikeslip faulting which placed the PBF formation over the DRB formation. Based on radiometric age dating of boitite in the fault zone this deformation is Paleozoic in age (approximately $300 \mathrm{ma}$ ago). In addition, to ductile deformation features, the subCretaceous basement rocks also record the effects of brittle deformation episodes characterized by fractures, brittle faults, and frictional melting. The presence of mineralized veins associated with these fractures and brittle faults indicate that the brittle faulting was often accompanied by the movement of hot waters . Radiometric dating of these effects suggest that at least one phase of brittle deformation occurred around 220 million years ago. This age would make this phase of brittle deformation most likely associated with formation of the Dunbarton basin. Other younger brittle deformation features are also present which are most likely associated with Tertiary deformation in the basement such as the Pen Branch Fault. Radiometric dating of fracture filling yielded an age of 23 million years. However the radiometeric systematics of the mineral dated are not well known so the geologic meaning of this age is uncertain. 


\section{REFERENCES}

Anderson, E.E., 1990, The Seismotectonics of the Savannah River Site: The Results of a detailed gravity survey: M.Sc. thesis, University of South Carolina, Columbia, 246p.

Bartholomew, M.J., Lewis, S.E., Evans, M.A., Rich, F.J., Brodie, B.M., Heath, R.D., Greenwell, R.A., Pray, J.R., Whitaker, A.E., Blanchard, J.S., Syms, F.H., 1997, Regional structural controls on the Coastal Plain hydrologic regime in westcentral South Carolina and adjacent Georgia, Year Three Report Task order 169, for Westinghouse Savannah River Company.

Chapman, W.L., and DiStefano, M.P., 1989, Savannah River Plant Seismic Survey, 1987-88: CONOCO Inc., Seismic Acquisition Section, Research Report 1809005-006-1-89, 110p.

Cumbest, R.J., Price, V. and Anderson, E.E., 1992, Gravity and magnetic modeling of the Dunbarton Triassic basin, South Carolina: Southeastern Geology, v.33, n.1,p.37-51.

Cumbest, R.J., Domoracki, W.J. (1998) Quantitative interpretation of steep basement reverse faulting from seismic reflection data. in Geotechnical Site Characterization, Proceedings of the First International Conference on Site Characterization - ISC'98, Atlanta, Ga., 19-22 April 1998. Peter K. Robinson and Paul W. Mayne eds.

Daniels, D.L., 1974, Geologic Interpretation of Geophysical Maps, Central Savannah River Area, South Carolina and Georgia: U.S. Geological Survey Geophysical Investigations Map GP-893. 
Daniels, D.L., Zietz, I, and Popenoe, P., 1983, Distribution of subsurface lower Mesozoic rocks in the Southeastern United States as interpreted from regional aeromagnetic and gravity maps; in Studies Related to the Charleston, South Carolina Earthquake of 1886 - Tectonics and Seismicity: U.S.G.S. Professional Paper 1313-K, p.1-24.

Dennis, A.J., Maher, H.D., Jr., Mauldin, J.C. and Shervais, J.W., 1997, Repeated Phenerozoic reactivation of a southern Applachian fault zone beneath the up-dip coastal plain of South Carolina.

Domoracki, W.J., 1994, A geophysical investigation of geologic structure and regional tectonic setting at the Savannah River Site, South Carolina. Ph.D. dissertation, Virginia Polytechnic Institute, Blacksburg, Va.

Latour, T.E., Roden, M.F., Vanko, D.A. and Whitney, J.A., 1995, Crystalline basement core - Savannah River Site: Final Report, ERDA Task 53, 303p.

Marine, I.W., Siple, G.E., 1974, Buried Triassic Basin in the Central Savannah River Area, South Carolina and Georgia: Geological Society of America Bulletin, v.85, n.2, p.311-320.

Shervais, J.W., Mauldin, J. and Dennis, A.J., 1997, Petrology and geochemistry of Neoproterzoic Arc plutons beneath the Atlantic coastal plain: Savannah River Site, South Carolina.

Seismograph Service Corporation, 1971, Report on Seismograph Surveys Conducted in Barnwell and Aiken Counties, South Carolina, WR860040, Savannah River Plant Bedrock Waste Storage. A report prepared for E.I. DuPont De Nemours and Company, Inc. 
Stephenson, D. and Stieve, A., 1992, Structural model of the basement in the central Savannah River area, South Carolina and Georgia: USDOE Report WSRC-TR92-120, Westinghouse Savannah River Company, Savannah River Site, Aiken South Carolina, $18 \mathrm{p}$.

Wyatt, D.E., Cumbest, R.J., Aadland, R.K., Syms, F.H., Stephenson, D.E., Sherrill, J.C. (1997a) Investigation on the combined use of ground penetrating radar, cone penetrometer and high resolution seismic data for near surface and vadose zone characterization in the $\mathrm{A} / \mathrm{M}$ area of the Savannah River Site, South Carolina (U): Upper Three Runs Watershed A/M Area Advanced Geologic Study Part 1 of 3. WSRC-RP-97-0184, Revision 0, 49p.

Wyatt, D.E., Cumbest, R.J., Aadland, R.K., Syms, F.H., Stephenson, D.E., Sherrill, J.C. (1997b) Interpretation of geological correlation borings $1,2,3$ in the $A / M$ area of the Savannah River Site, South Carolina (U): Upper Three Runs Watershed A/M Area Advanced Geological Study Part 2 of 3. WSRC-RP-97-0185, Revision 0, 28p.

Wyatt, D.E., Aadland, R.K., Cumbest, R.J., Stephenson, D.E., Syms, F.H. (1997c) Geological interpretation of the structure and stratigraphy of the $\mathrm{A} / \mathrm{M}$ area, Savannah River Site, South Carolina (U): Upper Three Runs Watershed A/M Area Advanced Geological Study Part 3 of 3. WSRC-RP-97-0186, Revision 0, $46 \mathrm{p}$. 


\section{LIST OF FIGURES}

Figure 1. Character of the unweathered rock event as modeled from acoustic velocity and density logs from borings. Synthetic model traces (normal) compared to real reflection profile (SRS-1). Lithology information from core $\log$ ( \%MU in green; \%SAND in yellow). Vertical scale linear in time.

Figure 2. A typical seismic reflection profile from Savannah River Site. The unweathered rock event is the approximate boundary between overlying sedimentary sequences and basement. The contrast in physical properties across this boundary make it a relatively strong and easily identified reflection event. The sedimentary sequences are layered an strongly reflecting producing many reflection events in the upper part of the section above the unweathered rock event. Examples of one-half and one-quarter wavelength offsets are identified.

Figure 3. Basement surface topography with faulting.

Figure 4. Seismic data set used for mapping the basement surface and faulting with the exception of Seismograph Services Corporation lines 1 extension and Line 7. Major regional faults shown. Other mapped offsets indicated by symbol.

Figure 5. Basement surface fault map for Savannah River site. Major regional faults shown and named. Inferred orientations and extents of faults inferred from offsets show.

Figure 6. Fracture development sequence for the Savannah River Site and surrounding region (from Bartholomew and others, 1997). Fracture set nomenclature based on the geologic time period of their creation (i.e. $\mathrm{T}=$ Triassic, $\mathrm{J}=$ Jurassic, $\mathrm{E}=$ Eocene, $\mathrm{M}=$ Miocene; $\mathrm{P}=$ Pliocene) and their sequence within the time period ( i.e. $1,2,3$, etc.). 
Figure 7. Seismic reflection profiles illustrating examples of typical offset of the basement surface associated with the major faults on the Savannah River Site. a. Pen Branch Fault, b. Crackerneck Fault, c. Atta Fault, d. Tinker Creek Fault.

Figure 8. Schematic illustration of the principals of data acquisition for the seismic reflection technique.

Figure 9. Modeling the wavelet response of a layered earth.

Figure 10. Gravity and magnetic anomalies from a 30 meter offset on the basement surface for various lithologic compositions and fault orientations. a) Felsic composition; north - south fault. b.) Metamorphosed mafic composition; north south fault. c) Mafic composition; north - south fault. d) Felsic composition; east - west fault e) Metamorphosed mafic composition; east - west fault; f) Mafic composition; east - west fault.

Figure 11. Sub-Cretaceous basement lithologies for Savannah River Site and vicinity (from Dennis and others, 1997)

Figure 12. Simple Bouguer gravity map of Savannah River Site and vicinity with postEarly Cretaceous faulting.

Figure 13. Aeromagnetic residual anomaly map for Savannah River Site and vicinity with post-Early Cretaceous faulting. 


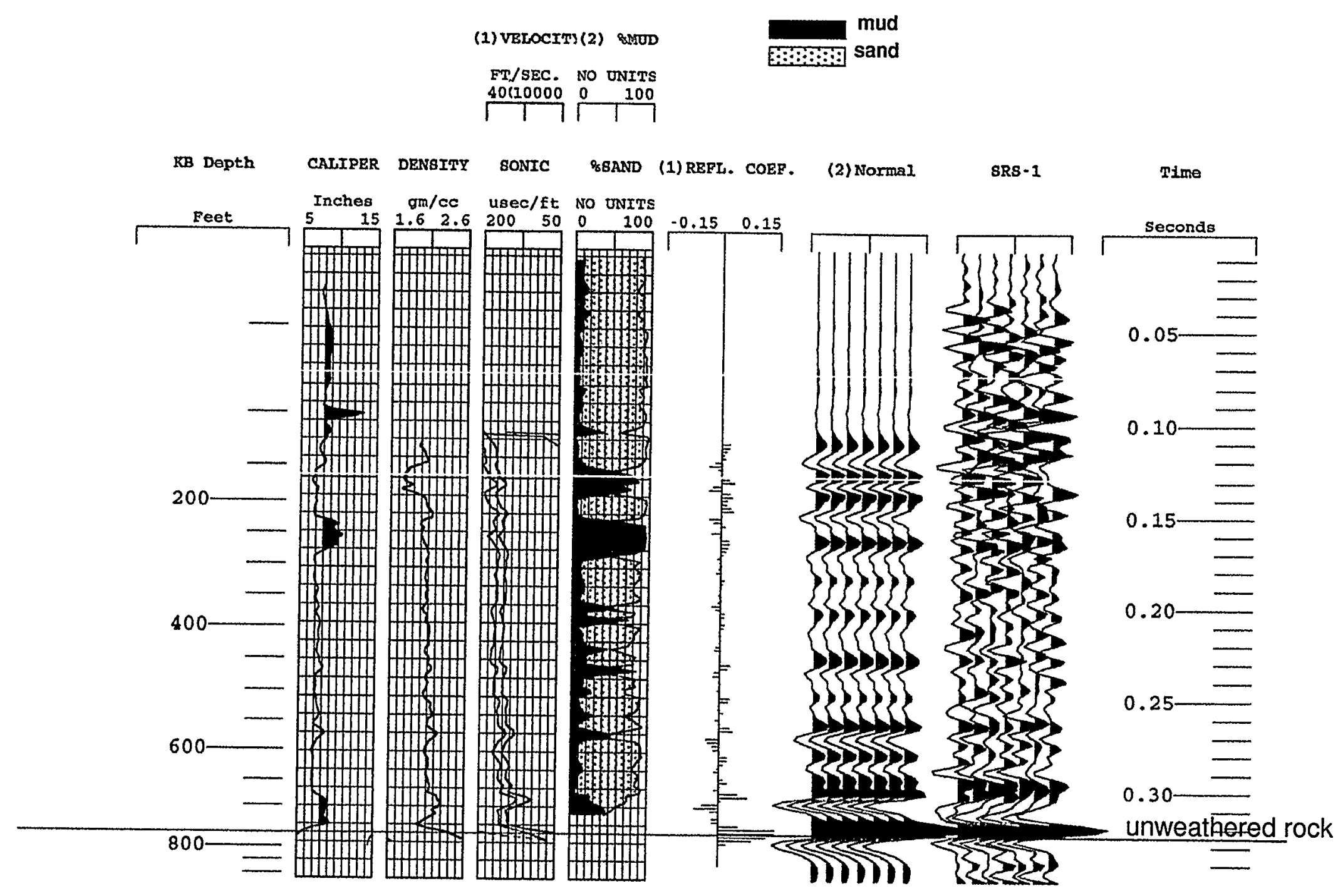

Figure 1. Character and identification of unweathered rock event as modeled from acoustic velocity and density logs (Normal) and as seen in seismic reflection data (SRS-1). Vertical scale is linear in time. 


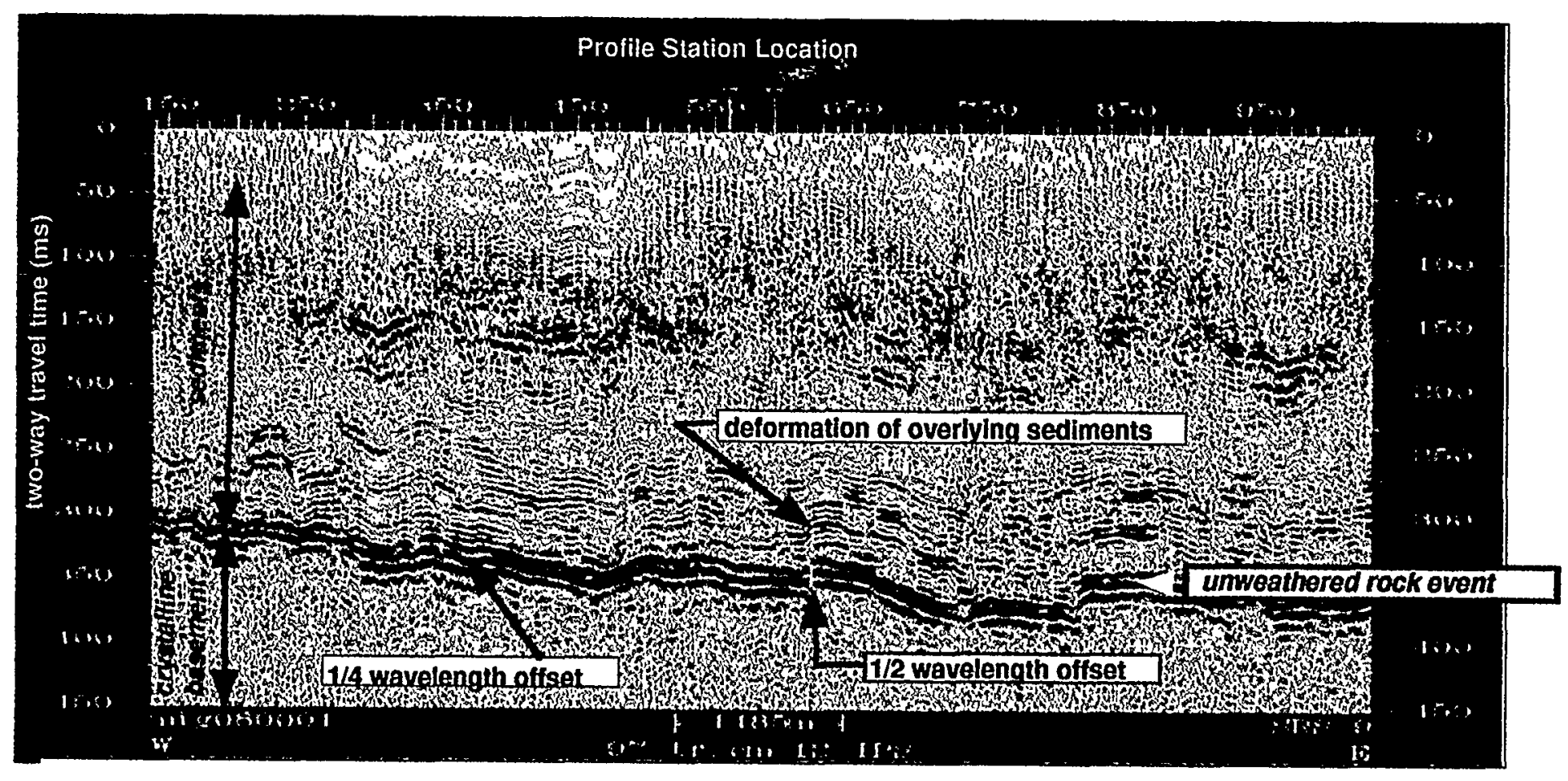

Figure 2. A representative seismic reflection profile from Savannah River Site (CONOCO line SRS-9). The unweathered rock event is the approximate boundary between overlying sedimentary sequences and basement. The contrast in physical properties across this boundary make it a strong and easily identified reflection event. The sedimentary sequences are strongly layered producing many reflections in the upper part of the section. Examples of $1 / 2$ and $1 / 4$ wavelength offsets in addition to sediment deformation are identified. The vertical scale is significantly exaggerated to enhance offsets. 


\section{Notice}

Page(s) size did not permit electronic reproduction. Information may be purchased by the general public from the National Technical Information Service, U.S. Department of Commerce, Springfield, VA 22161 (1800-553-6847). DOE and DOE contractors may purchase information by contacting DOE's Office of Scientific and Technical Information, P.O. Box 62, Oak Ridge, TN 37831-0062, Attn: Information Services (1865-576-8401). 


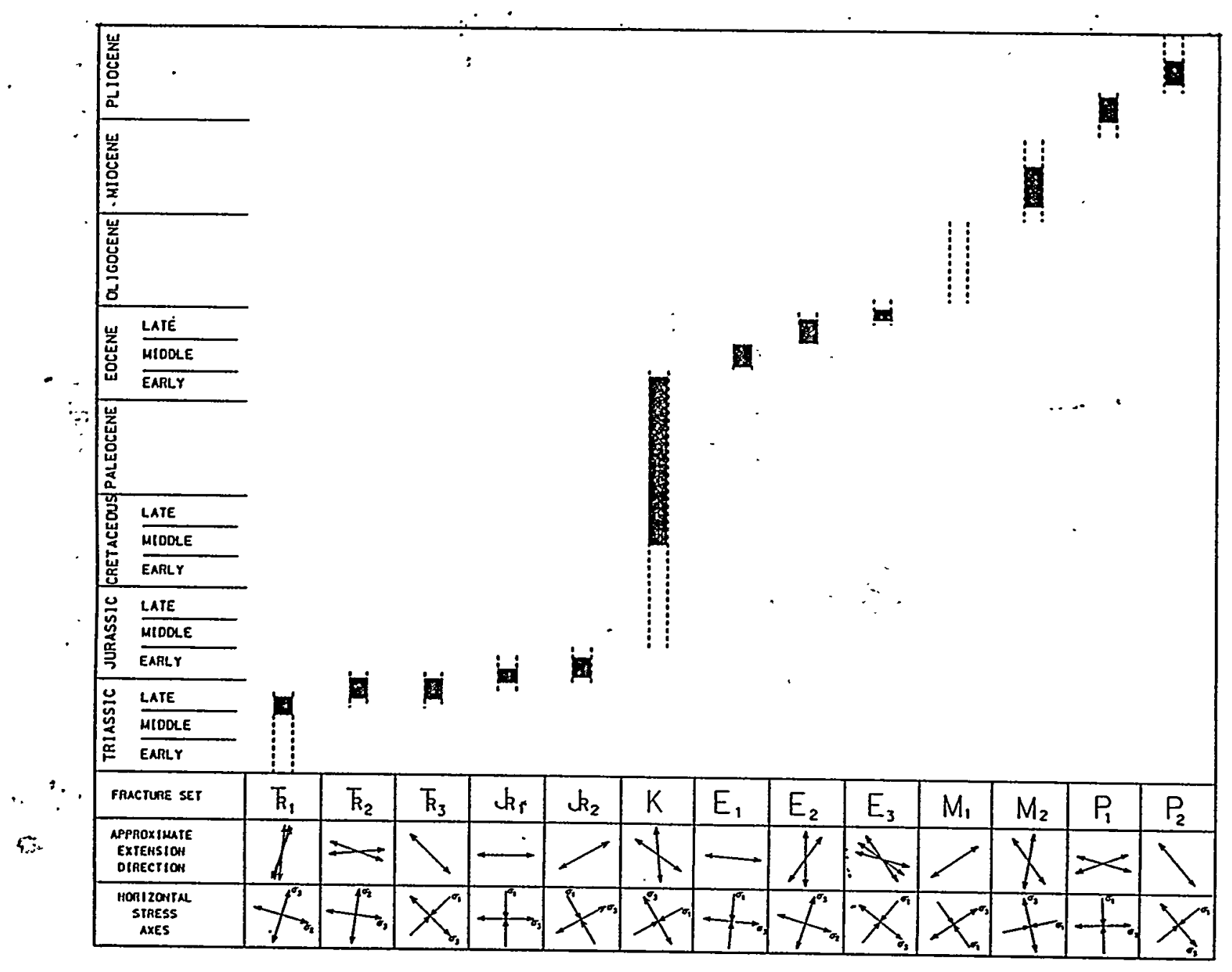

Figure 6. Fracture development sequence for the Savannah River Site and surrounding region (from Bartholomew and others, 1997). Fracture sets nomenclature based on the geologic time period of their creation (i.e. $\mathrm{T}=$ Triassic, $\mathrm{J}=\mathrm{Jurassic}, \mathrm{E}=$ Eocene, $\mathrm{M}=$ Miocene, $\mathrm{P}=\mathrm{Pliocene}$ ) and their sequence within the time period (i.e. $1,2,3$, etc.). 


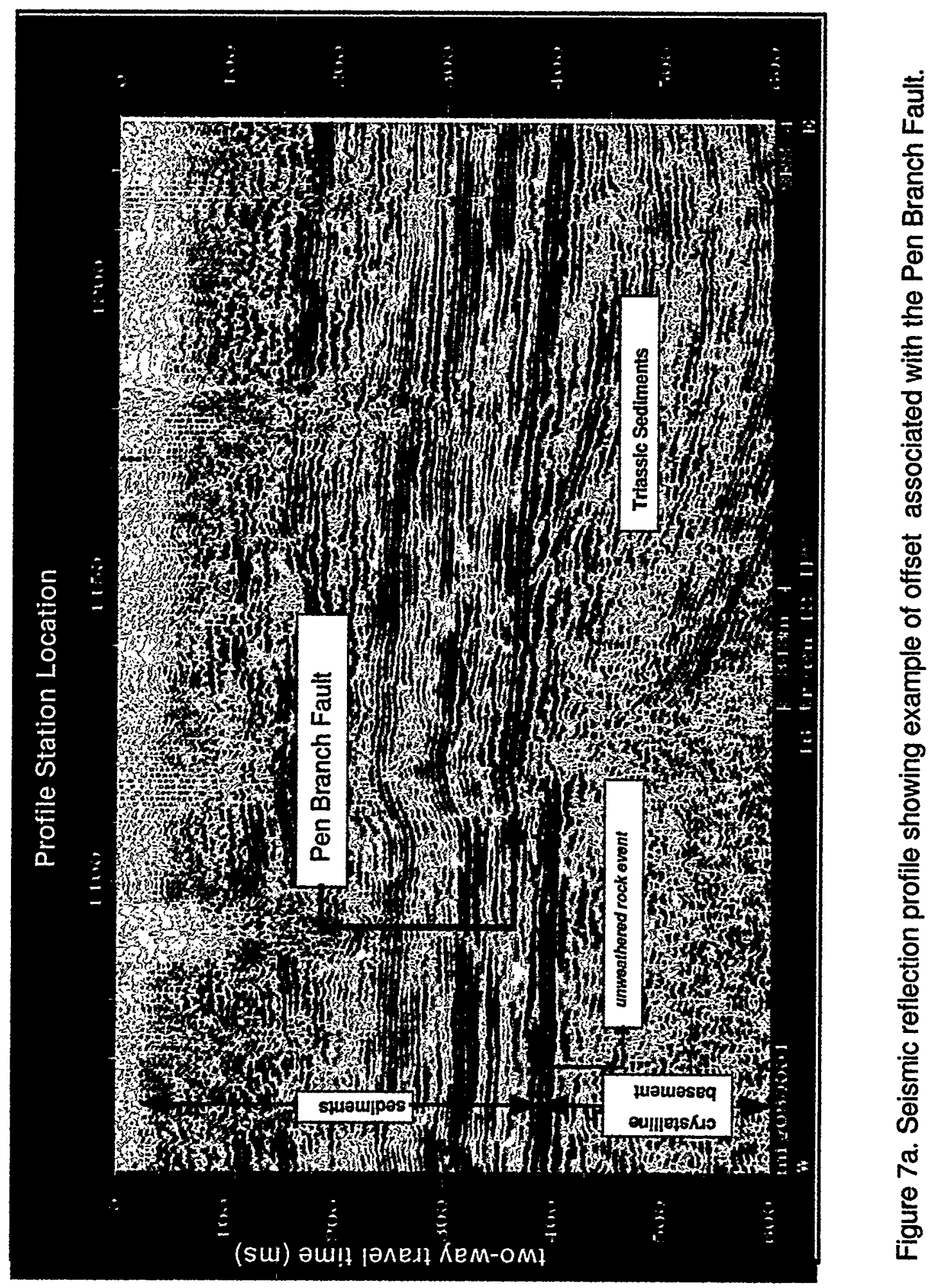




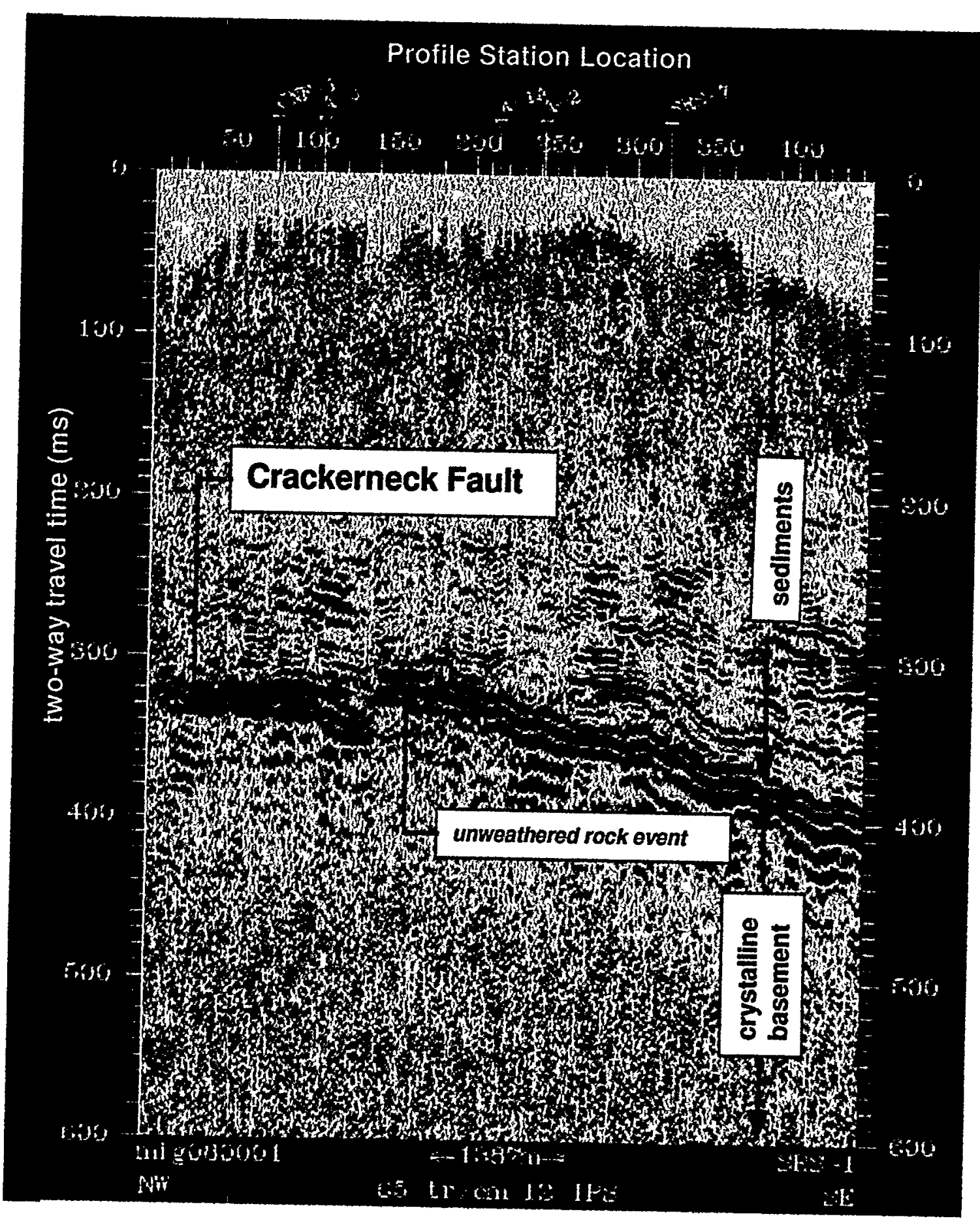

Figure $7 \mathrm{~b}$. Seismic reflection profile showing example of offset associated with the Crackerneck Fault. 


\section{Profile Station Location}

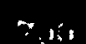

$\because \because$

Si:i,

$4=$

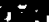

(1)

Pot

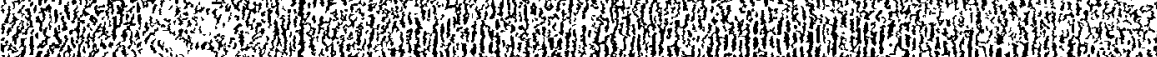
औ.

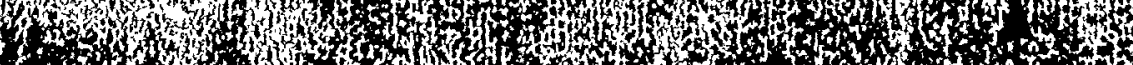

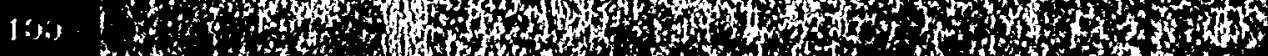

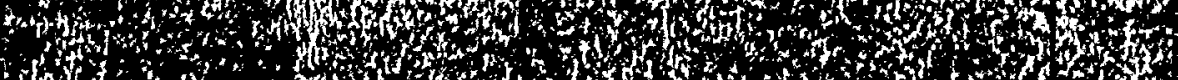

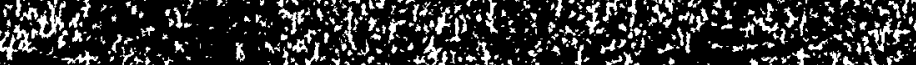

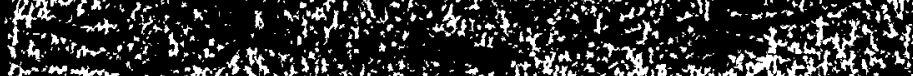

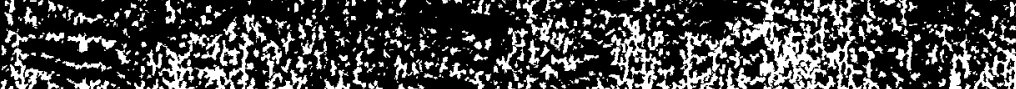

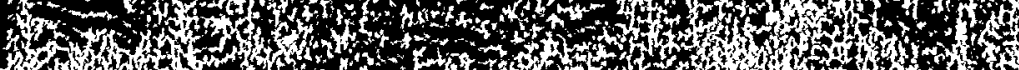

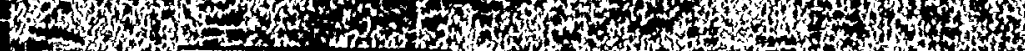

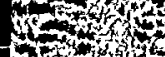
7.7ta Fault

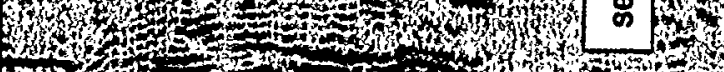
and D.

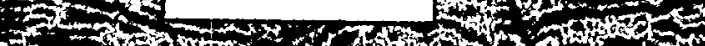

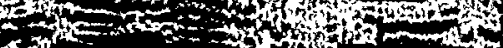

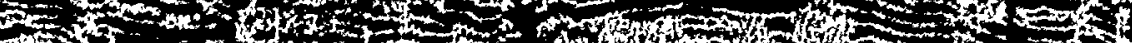

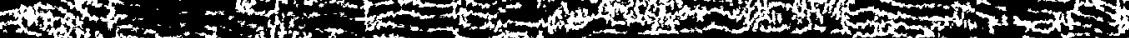
Arom $=0$

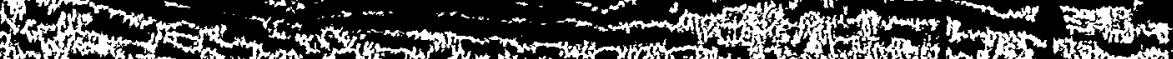

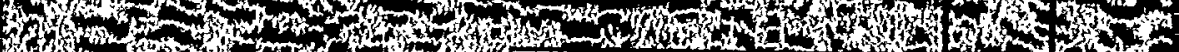

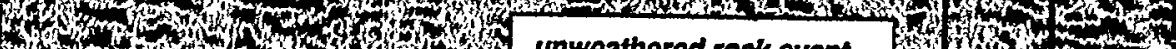

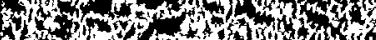
ondasion on unweatherod rock event

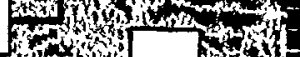

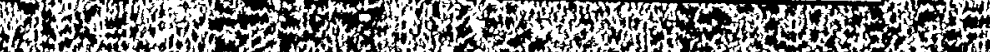

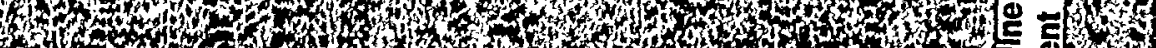

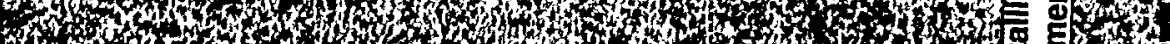

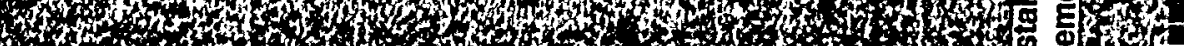

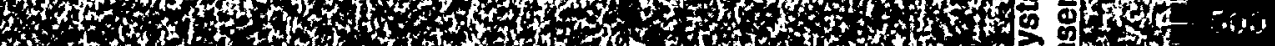

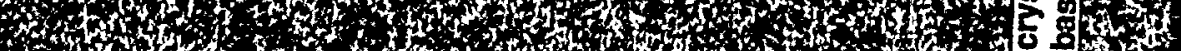

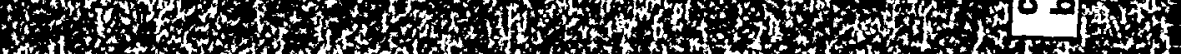

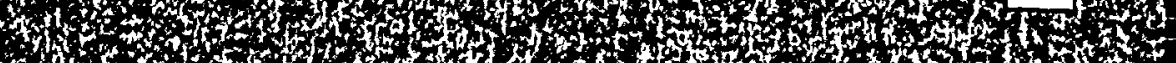

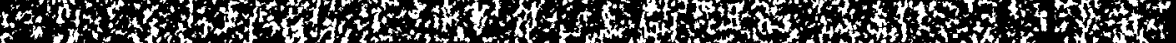

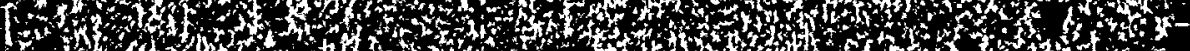

Figure 7c. Seismic reflection profile showing example of offset associated with the Atta Fault. 


\section{Profile Station Location}

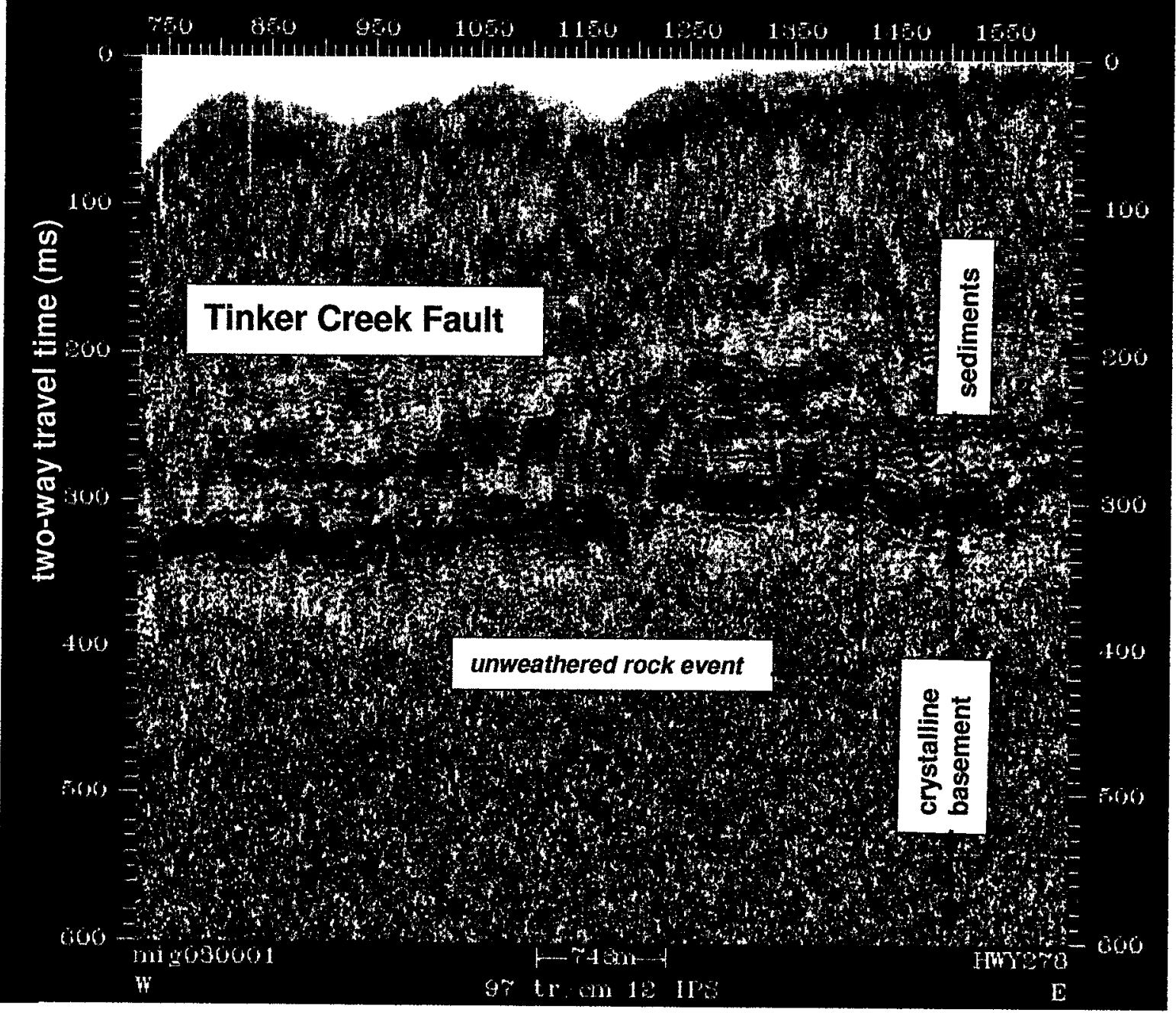

Figure 7d. Seismic reflection profile showing example of offset associated with the Tinker Creek Fault. 

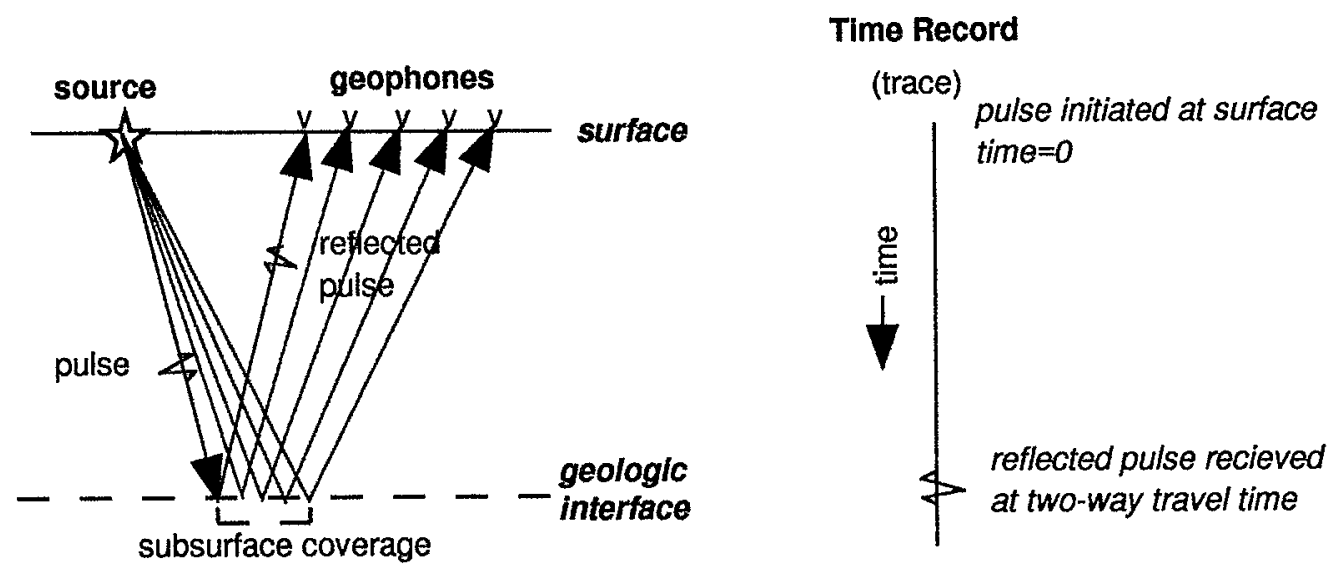

Figure 8. Schematic illustration of the principals of data acquisition for the seismic reflection technique.

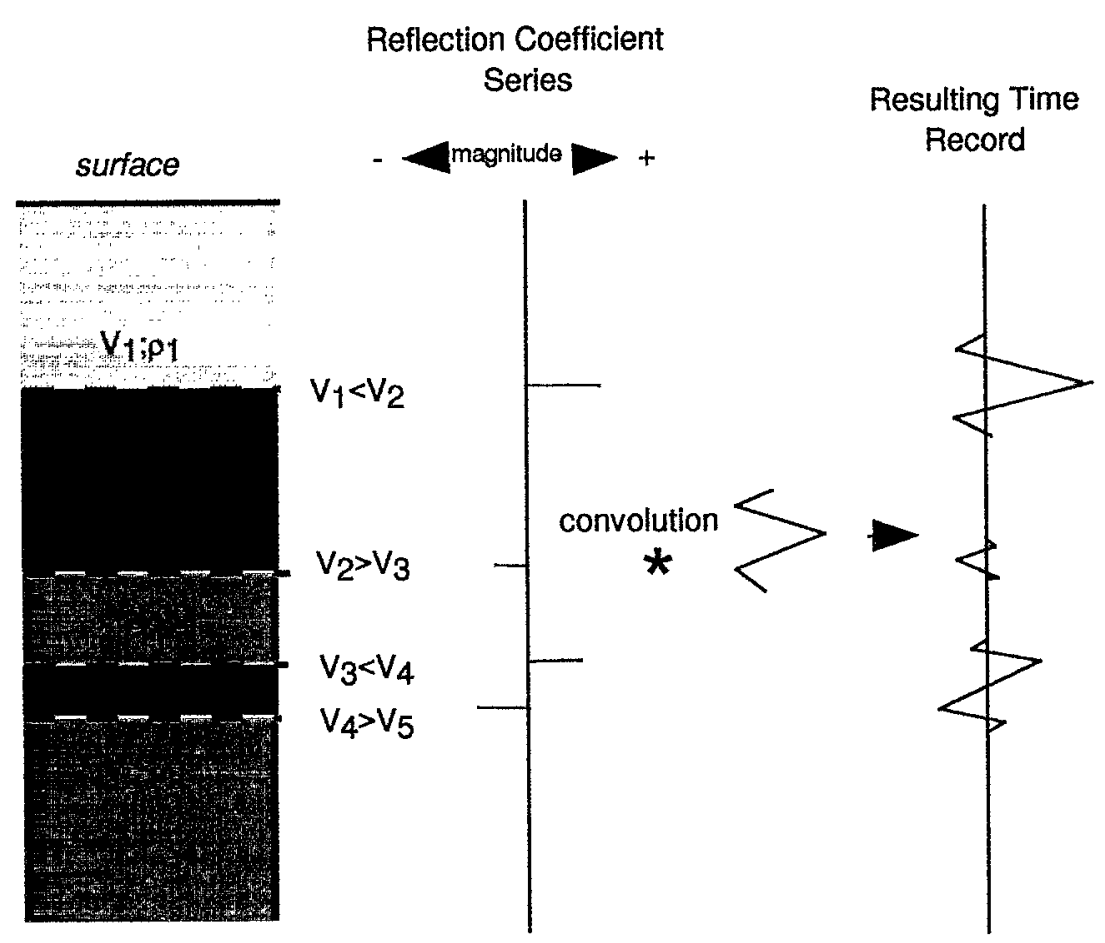

Figure 9. Modeling the wavelet response of a layered earth. 


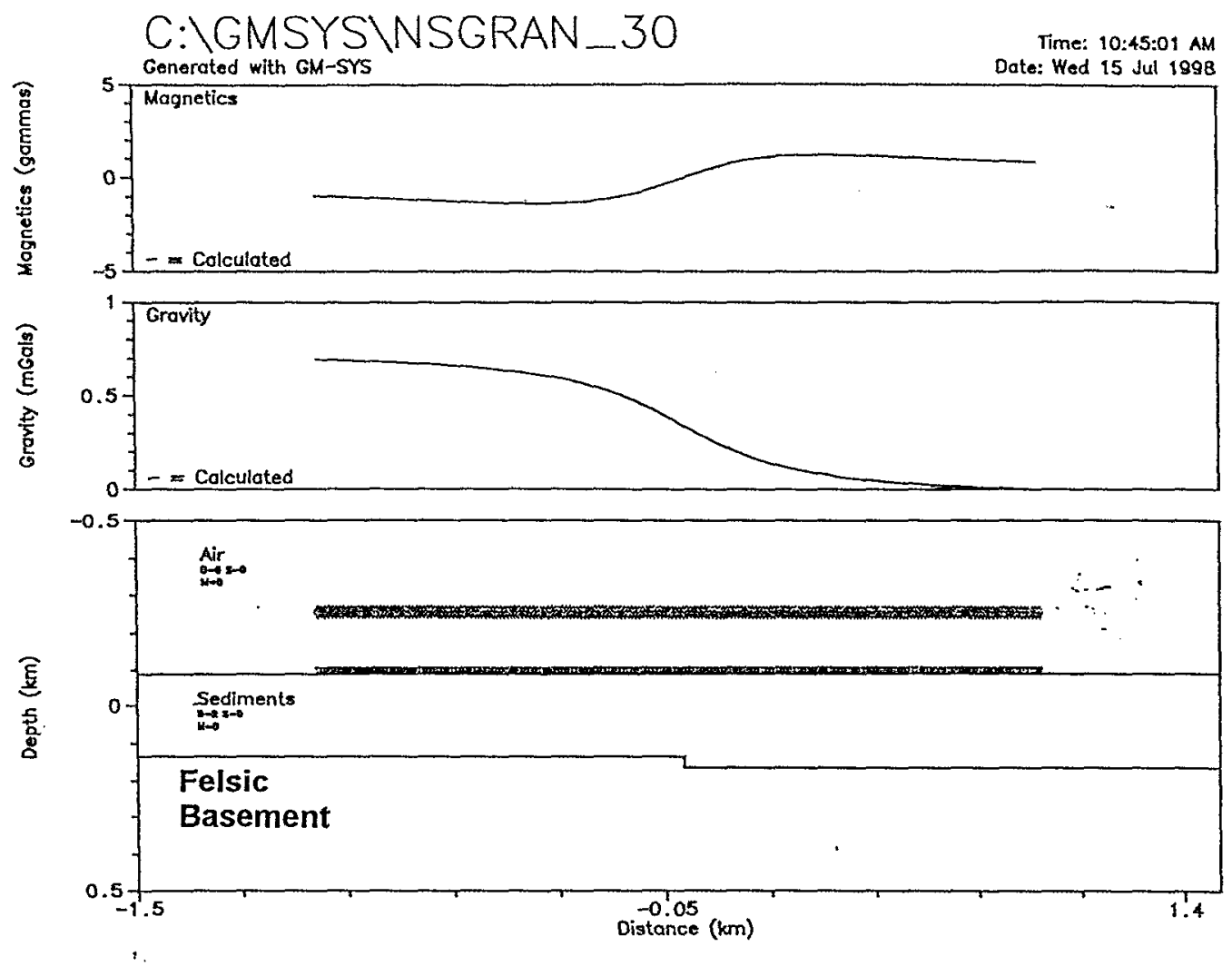

Figure 10a. Modeled gravity and magnetic anomalies for a 30 meter offset on the basement surface trending north - south. Basement lithology assumed to be felsic composition with a density of $2.65 \mathrm{~g} / \mathrm{cc}$ and magnetic susceptibility of $0.0004 \mathrm{emu}$. 


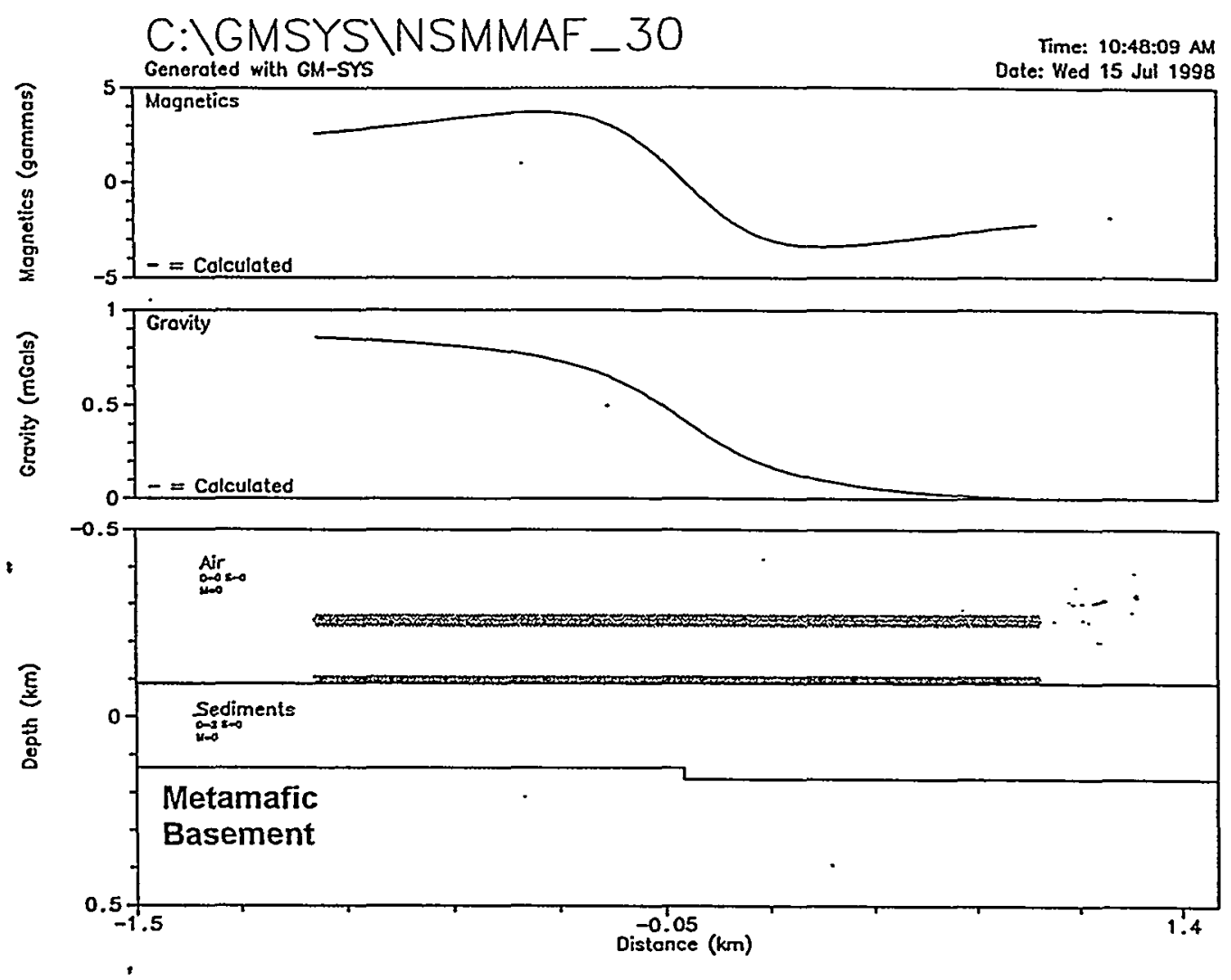

Figure 10b. Modeled gravity and magnetic anomalies for a 30 meter offset on the basement surface trending north - south. Basement lithology assumed to be metamorphosed mafic composition with a density of $2.8 \mathrm{~g} / \mathrm{cc}$ and magnetic susceptibility of $0.0011 \mathrm{emu}$. 


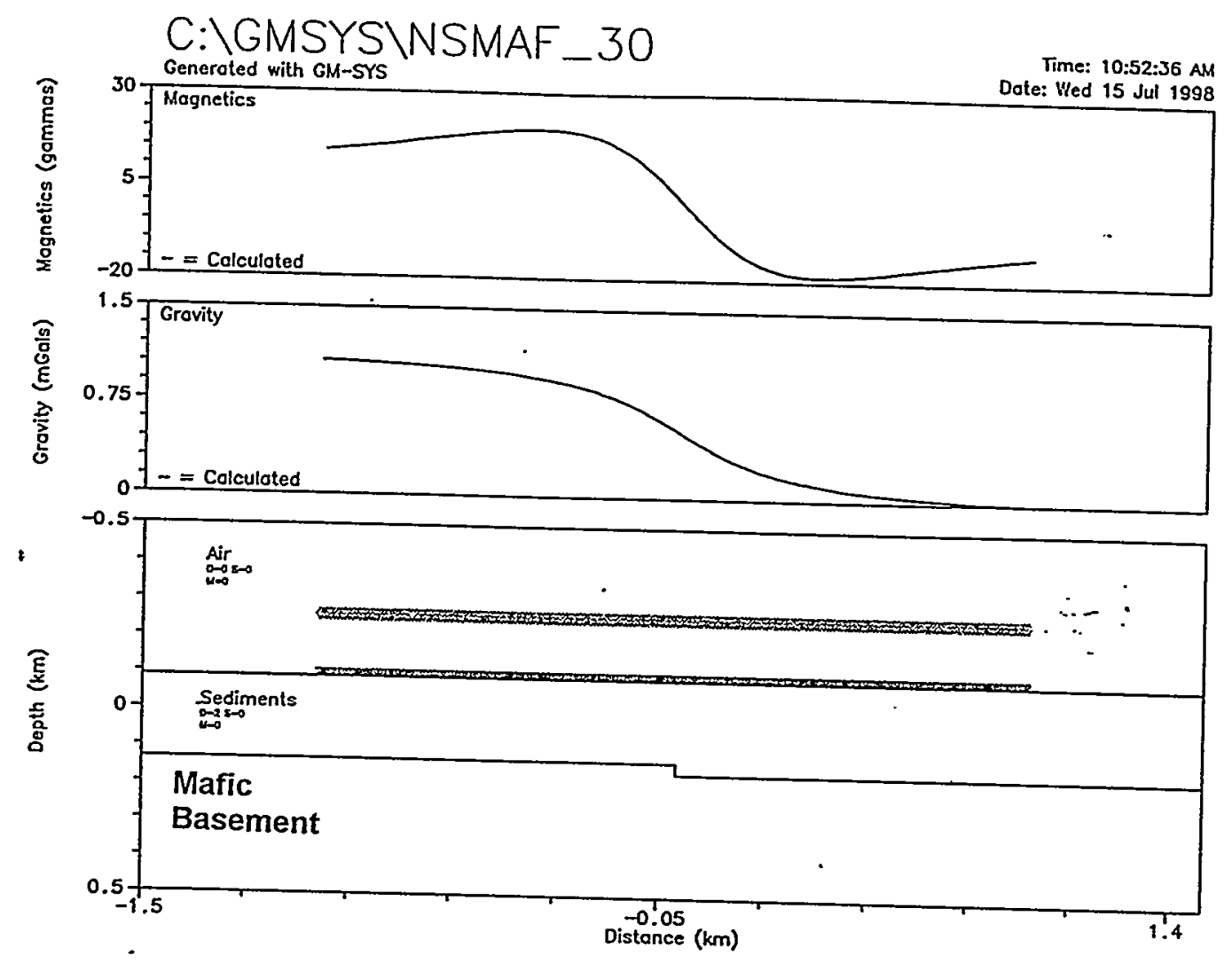

Figure 10c. Modeled gravity and magnetic anomalies for a 30 meter offset on the basement surface trending north - south. Basement lithology assumed to be mafic composition with a density of $3.0 \mathrm{~g} / \mathrm{cc}$ and magnetic susceptibility of $0.006 \mathrm{emu}$. 


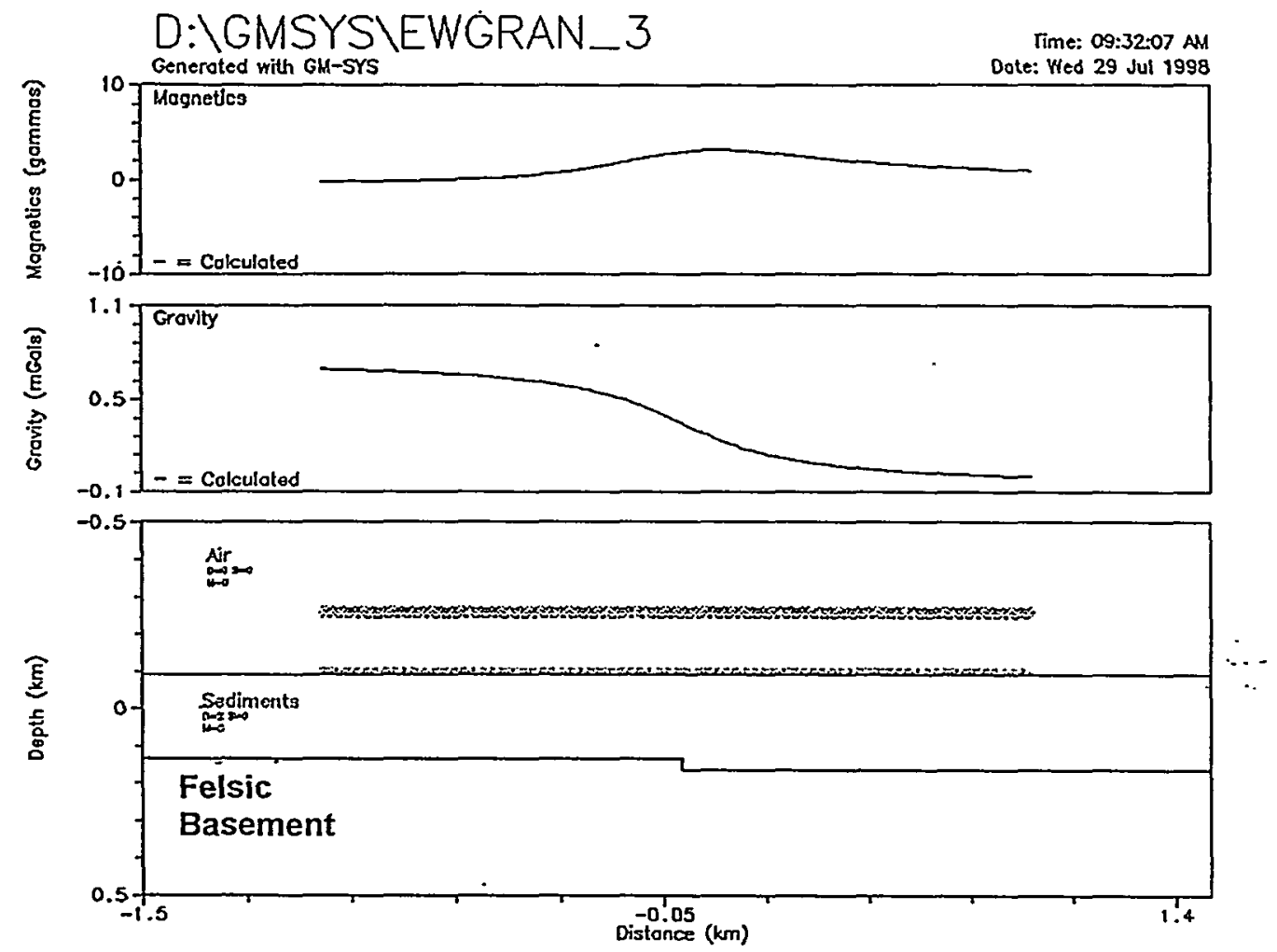

Figure 10d. Modeled gravity and magnetic anomalies for a 30 meter offset on the basement surface trending east - west. Basement lithology assumed to be felsic composition with a density of $2.65 \mathrm{~g} / \mathrm{cc}$ and magnetic susceptibility of $0.0004 \mathrm{emu}$. 


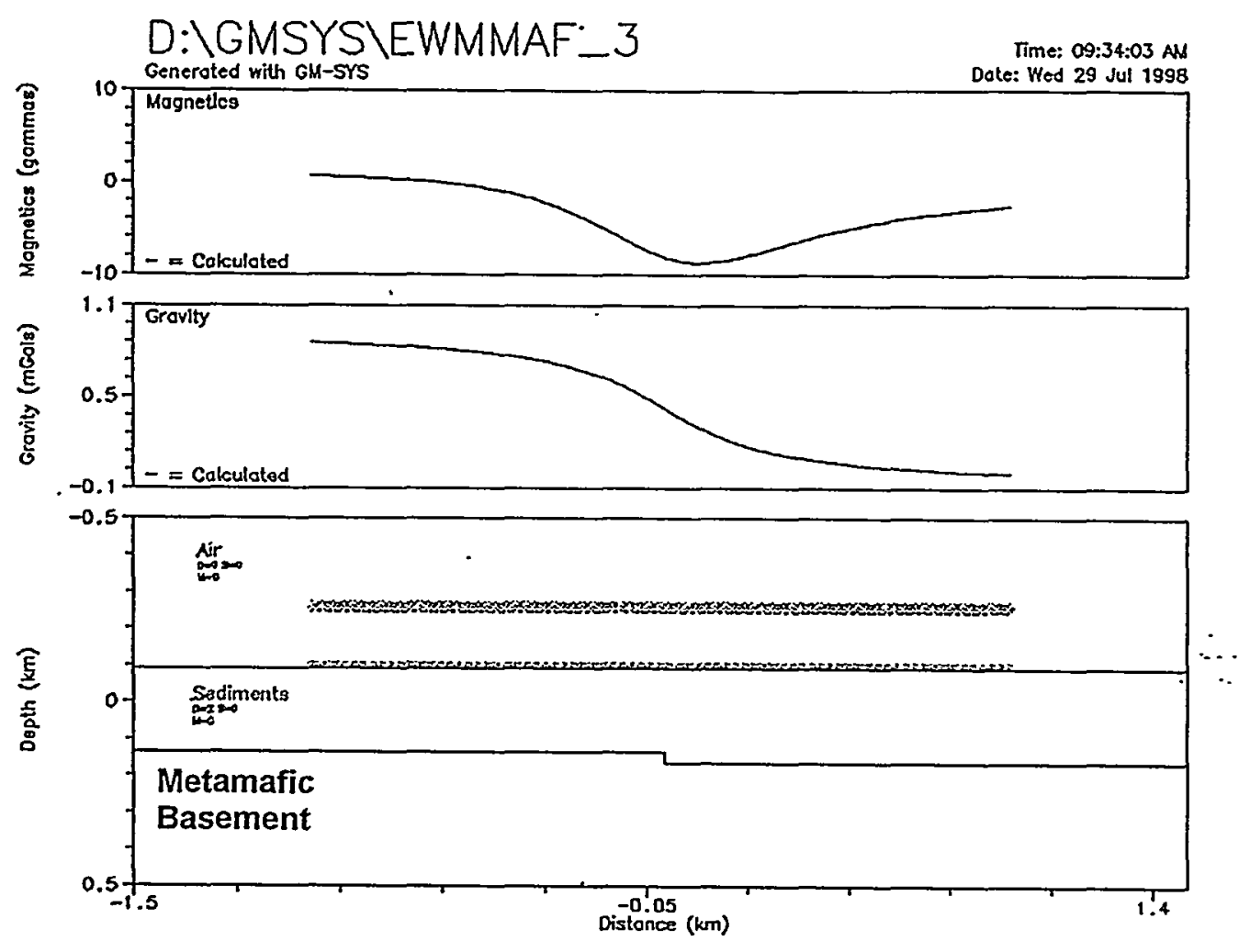

Figure 10e. Modeled gravity and magnetic anomalies for a 30 meter offset on the basement surface trending east - west. Basement lithology assumed to be metamorphosed mafic composition with a density of $2.8 \mathrm{~g} / \mathrm{cc}$ and magnetic susceptibility of $0.0011 \mathrm{emu}$. 


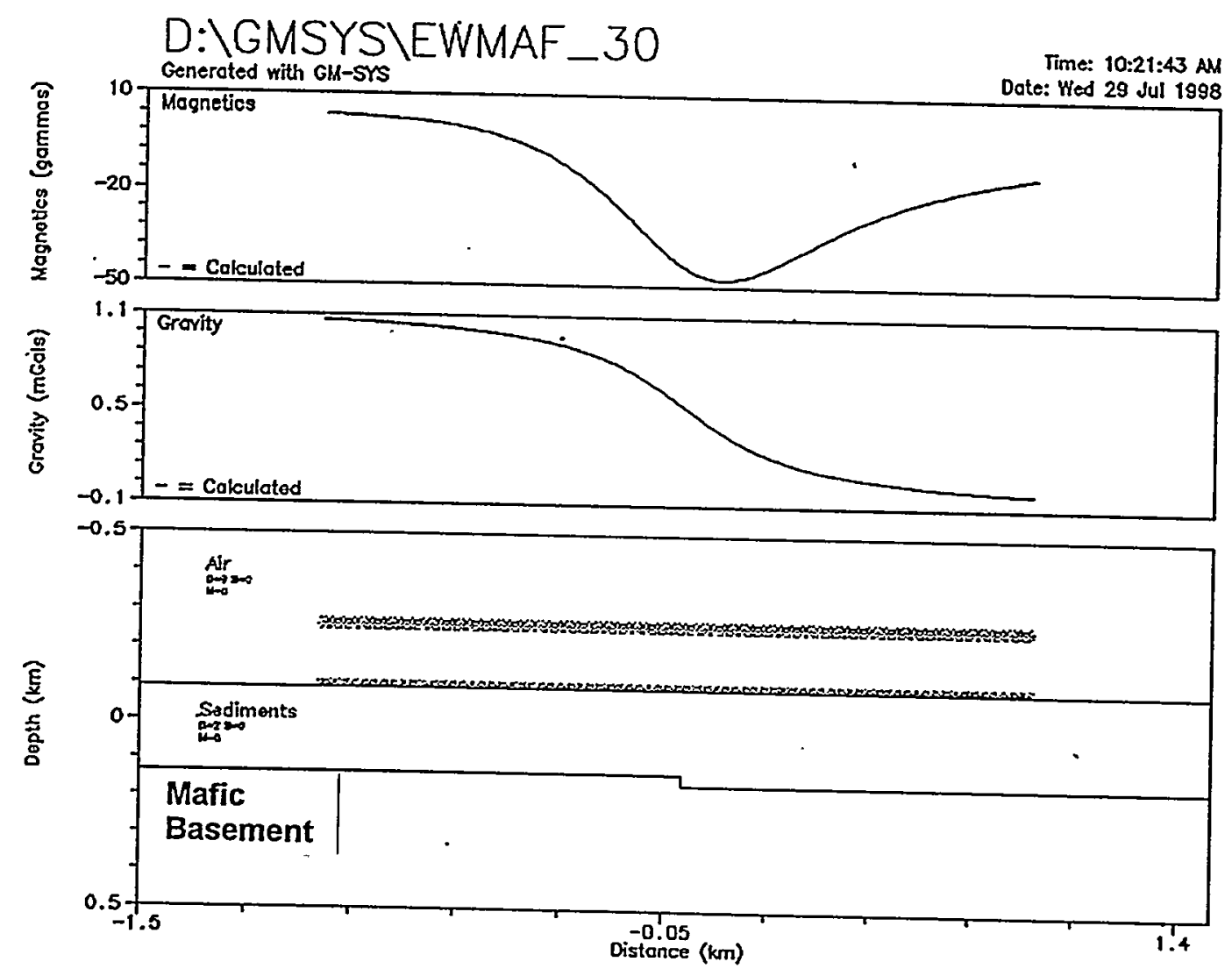

Figure 10f. Modeled gravity and magnetic anomalies for a 30 meter offset on the basement surface trending east - west. Basement lithology assumed to be mafic composition with a density of $3.0 \mathrm{~g} / \mathrm{cc}$ and magnetic susceptibility of $0.006 \mathrm{emu}$. 


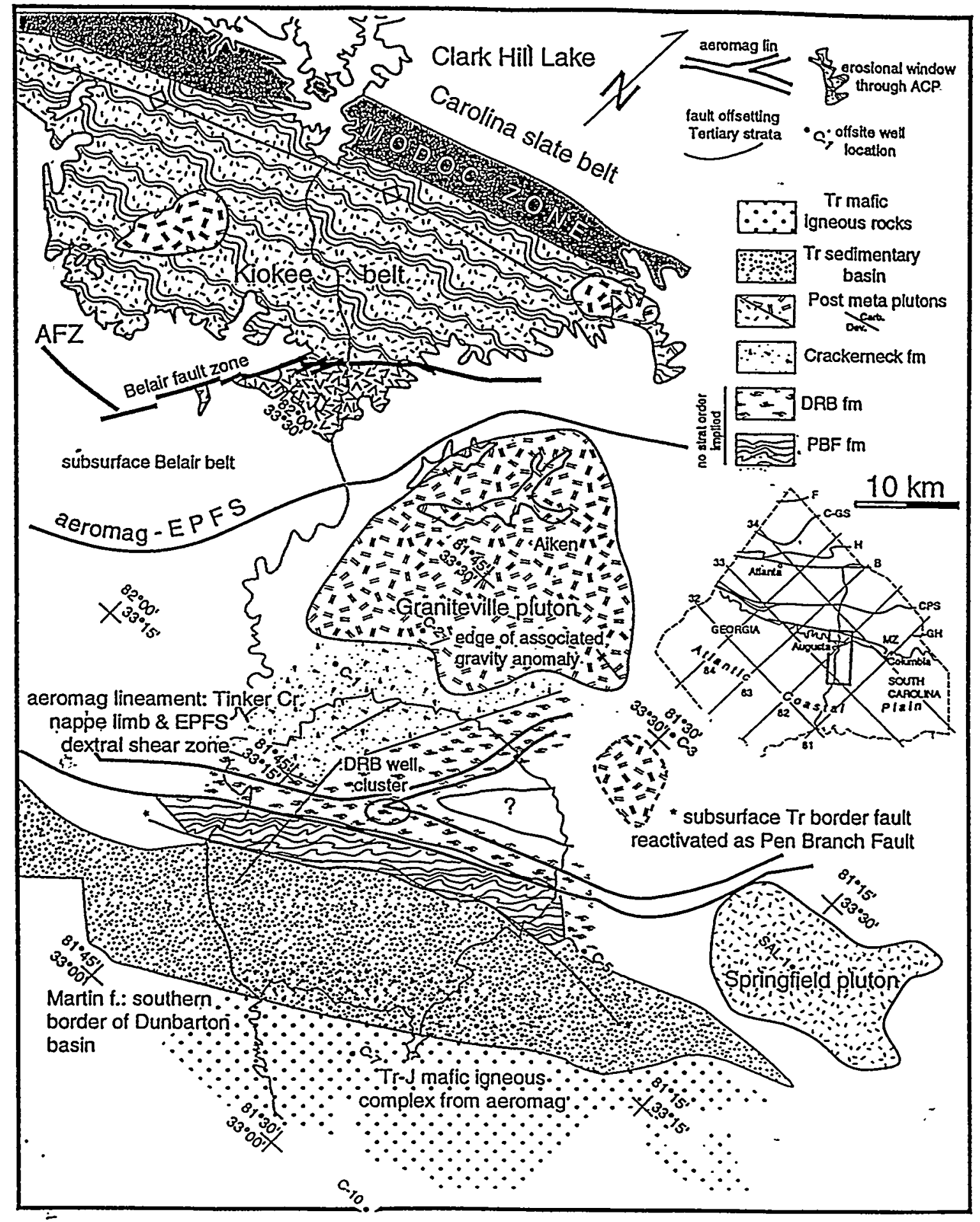

Figure 11. Sub-Cretaceous basement lithologies for the Savannah River Site and surrounding region (from Dennis and others, 1977) 
Notice

Page(s) size did not permit electronic reproduction. Information may be purchased by the general public from the National Technical Information Service, U.S. Department of Commerce, Springfield, VA 22161 (1800-553-6847). DOE and DOE contractors may purchase information by contacting DOE's Office of Scientific and Technical Information, P.O. Box 62, Oak Ridge, TN 37831-0062, Attn: Information Services (1865-576-8401). 